\title{
CAN ORGANISATION CAPITAL IMPROVE CORPORATE PERFORMANCE THROUGH DIRECT PATH OR MEDIATING EFFECT SURVEILLANCE OF BOARD FUNCTION: EVIDENCE FROM TAIWAN?
}

\author{
Mu-Shun WANG ${ }^{\mathrm{a}}$, Shih-Tong $\mathrm{LU}^{\mathrm{b}}$ \\ ${ }^{a}$ Graduate School of Banking and Finance, Kainan University, No.1 Kainan Road, \\ Luzhu Shiang, 33857, Taoyuan, Taiwan (ROC) \\ ${ }^{b}$ Department of Banking and Finance, Kainan University, No.1 Kainan Road, \\ Luzhu Shiang, 33857, Taoyuan, Taiwan (ROC)
}

Received 10 September 2013; accepted 24 June 2014

\begin{abstract}
This paper examines whether board function is associated with improved corporate performance. Path analysis is used to investigate the direct and indirect links between four performance variables and organization capital. A hypothesis is developed based upon the incorporation of knowledge-based resources. The idea is that the board of directors has monitoring and consultation functions, propelling organizational development. We use panel data with random effects for 1,355 firms listed on the Taiwan Stock Exchange from 2001 to 2012. The two-stage leastsquares method is used to explore the mediating effect among board function, organization capital and corporate performance. Both an aggregated model and the EP model are investigated specifying both a direct link and a mediated link with organization capital. It is concluded that the governance effect has a direct influence in the relationship between board function and corporate governance, and that organization capital is significantly associated with the performance variables. In terms of the counselling function of the board, inside directors are significantly related to dynamic capacity, which improves corporate performance for the long run.
\end{abstract}

Keywords: organization capital, relational capital, panel data, board function, mediating effect.

JEL Classification: G12, G34, P2.

\section{Introduction}

Prior studies have suggested that good organisation capital can serve as an effective mechanism for strengthening management ability so as to improve a firm's competitive advantage and thereby increase firm value (e.g., Eisfeldt, Papankolaou 2013; Fairer, Stainbank 2003; Gan, Saleh 2008; Tronconi, Marzetti 2011). Organisation capital is comprised of

Corresponding author Mu-Shun Wang

E-mail: sunrise034@yahoo.com.tw 
organisational culture, management philosophy, organisational processes, systems and informational resources. Several studies have focused on how the accumulation of valuable resources and capabilities arise from good corporate governance. For example, Ling (2013) and $\mathrm{Wu}$ et al. (2012) verified that corporate governance is a moderator in the process of the improvement of intellectual capital and organisation performance, the development of competitive advantage (Martin-de-Castro et al. 2006), the maintenance of sustainable development (Barbier 1987), and the creation of knowledge to develop new competencies through organisational transformation (Carayannis, Alexander 2002).

One neglected area of research has been the effect of management decision making on the development of organization capital, perhaps because the monitoring and auditing of such capital is difficult (Lampel et al. 2014). According to the dynamic capabilities framework, to obtain a competitive advantage and sustain development, a business needs to combine organization capital with firm-specific knowledge. It is recognized that high levels of skill and competency are essential to future capital success, to ensure the quality of goods and services that are delivered to the customer, as well as the development of new innovations to offer to the market. However, the causal relationship between corporate governance, organization capital and corporate performance has not been clearly explored through longitudinal analysis. It has been shown that the efforts of management lead to greater organization capacity and the generation of a general aura of confidence for the firm. However, to the best of our knowledge, there is has been no empirical research as to whether and how the monitoring of board function leads to improvement of organization capital or whether this has a direct impact on CEO performance and corporate governance. This study aims to fill this gap by investigating whether the characteristics of the board and organization capital have a governance effect on firm performance. In particular, we examine whether board function has a direct or indirect influence on management decisions and sustaining firm value. Data from Taiwan are tested because of the availability of longitudinal data for listed firms, a large percentage of which comprise high R\&D industries where the creation of organization capital is a priority. The results in this study should provide us with a better understanding of how various aspects of board functioning determine organization capital and corporate performance.

The sample includes 23,055 yearly observations for 1355 firms listed on Taiwan's stock exchange during the period from 2001-2012. In the first set of tests, organization capital is related to the dynamic capability hypothesis and corporate governance in terms of functioning of the board. We find that greater organization capital, as measured for each of its components, is significantly associated with better corporate performance and lower agency costs, as well as more insider shareholding. In particular, agency costs are lower and board strength less in firms demonstrating greater evidence of organization capital. Such capital is generated by innovation capital and relational capital. These observations are consistent with the conclusions of Demirag et al. (2000) and Abdullah (2004). This leads to the suggestion that there should be a serious commitment to the enforcement of corporate governance rules in Taiwan. Agency costs are also lower and board strength greater when top management pays more attention to investment in R\&D and to the development of customer relationships. Furthermore, the economic consequences suggest that organization capital has an economically meaningful association with corporate performance. 
Our results add new insights to the existing corporate governance literature for a large, fast-growing, and newly industrialized economy such as Taiwan's. We find that the governance mechanisms of the board of directors play a significant role in reducing agency costs, and the association is robust in several panel data tests. As noted above, listed Taiwan companies are examined. The objectives of the study are (1) to verify that organization capital has a significantly positive effect on corporate performance; (2) to verify that organization capital has a mediating effect on the relationship between board function and corporate performance; and (3) to examine whether the board functions as both a monitoring and consulting tool in organizational development. The main variables (size, diversification and independent directors and CEO duality) are positively and significantly related to corporate performance. Our results suggest that organization capital can be improved by focusing on monitoring of the board. The productivity, profit and probability of growth can be enhanced by increasing organization capital, thereby ensuring sustainable long-term economic development of the firm in the face of market uncertainty.

We now take a look at several well-known examples of financial distress arising from governance failure world-wide. For example, the case of Kodak, where both the board of directors and CEO ignored changes in the business environment by continuing to rely on film, including its production, exhibition and archiving in the US. Decline in business occurred regardless of the development of organization capital and investment projects ${ }^{1}$. This pattern of decline can be seen in several other cases, such as for EMI music (UK), Nokia (Finland), Motorola (USA), Reader's Digest (USA), and Nintendo (Japan). Often, the controlling shareholders expropriated significant amounts of profits, and disputes over perceived inequities tarnished the firm's reputation. Examples of problems included reducing R\&D input, utilizing internal funds for non-profit objectives. Furthermore, poor monitoring of top management encouraged manipulation of earning by the upper echelons.

Eisfeldt and Papankolaou (2013) argued that "shareholders consider firms with high levels of organization capital to be riskier than firms with more physical capital". Additionally, "shareholders demand higher risk prima to invest in firms with high levels of organization capital relative to firms with more physical capital". Such claims stimulated our interest in investigating the link between organization capital, the functioning of the board and corporate performance in an emerging market like Taiwan's, and, in particular, assessing the extent to which it is influenced both by ownership-level and operation-level factors as demonstrated by uncertain variation in longitudinal data. Sustainable development of an organization assumes the increasing production of useful goods and services in order to satisfy the basic demands of customers and to meet owners' expectations (Barbier 1987). The dynamic capabilities theory offers some understanding as to what happened in events such as the bankruptcy of the Kodak film company. It allows firms to build a new basis for obtaining a competitive advantage. The organization has to develop more functions so as to acquire and integrate knowledge that will allow it to develop new competencies through the process of organizational transformation (Carayannis, Alexander 2002).

While there is an extensive theoretical literature on organization capital and firm performance (Eisfeldt, Papanikolaou 2013; Tronconi, Marzetti 2011; Bastos 2007), there is only a limited amount on corporate governance in the existing empirical literature 
and what few studies there are focus mainly on the role of inside directors (Markarian, Parbonetti 2007). Past findings indicate that a strong board of directors improves corporate governance and information transmission, helping to balance the interests of different stakeholders, attract capital from shareholders by creating profits, and retain human capital (Lin et al. 2012). The empirical findings suggest that firms rely heavily on dynamic capacities for organization capital, leading to the development of theoretical hypotheses. It is argued in the literature that the acquisition of organization capital is motivated primarily by directors, and that intellectual capital and corporate governance simultaneously have a multiplying effect on organization performance. However, the question arises, does corporate governance simultaneously affect performance as well as intellectual capital, or does corporate governance have an indirect effect on intellectual capital and intellectual capital a direct effect on performance?

To measure organization capital, we employ several firm-choice variables taken from prior intellectual capital research studies. We employ two innovation variables for the aggregated valuation within the Eisfeldt, Papanikolaou model (EP model) (2013) which is related to organization capital. Several measures are used to capture dynamic capabilities and board function from data that are readily available from the Taiwan Securities Market sample.

The rest of the paper is organized as follows: an overview of the literature on the importance of board function, organization capital and corporate performance is provided in Section 1; in Section 2, the methodology and the data collected for this study are described; in Sections 3 and 4, the empirical findings are presented; and in the last Section some conclusions are offered.

\section{Literature review}

\subsection{Organisation capital as a contributor to sustainable economic development}

Organization capital is basically "firm-specific human capital" (Prescott, Visscher 1980) and it captures learning effects. Rosen (1972) argued in favour of learning-by-doing stemming from the repeated use of physical capital. Atkeson and Kehoe (2005) used a structural model to prove that organization capital comprises important input into a firm's production capability and acts as a measure of its contribution. Bastos (2007) introduced a purely convex model that indicates that organization capital induces the properties of continuity and differentiability. It also facilitates the discovery, transfer and utilization of intra-organizational knowledge and is conducive to internal knowledge sharing (Serenko et al. 2007; Hall, Goody 2007). Organization capital can also be drawn from the knowledge of external stakeholders during the process of innovation to develop new products or services, or new products. Firms can improve performance through corporate restructuring, acquisitions and mergers and the implementation of strategic assets (Wernerfelt 1984). Organization capital includes intangible knowledge-related assets (Kuo, Yang 2012), and can have a significant effect on value creation and company performance resulting in sustainable development (Edvinsson, Malone 1997; Stewart 1997; Bontis 1999; Sullivan 2000; Juma, Payne 2004), 
which leads to more volatility across firms (Gomes et al. 2003; Kogan, Papanikolaou 2010). Maditinos et al. (2011) argued that intellectual capital is embedded in the organization and connected with the firm's knowledge and capabilities, making which render it a keystone for building a sustainable competitive advantage (Bontis 1999; Tronconi, Marzetti 2011) R\&D investment have been found to have a positive relationship with firm performance (Wang 2008). In short, there is a positive relationship between organization capital and business performance (Bontis et al. 2000). Organization capital leads to the accumulation of knowledge, the creation of sustainable economic value and has core benefits. Urban and Hauser (1993) stated that a firm must build on its understanding of expressed and latent customer needs, and that the organization gains through transformation and learning from its customers. The results must certainly be reflected in core benefits if the risk of failure is to be minimized. Hence, organization capital is likely to bring greater capability to foresee environmental and market changes, allowing the firm to make adjustments based on its dynamic capabilities. It is suggested that firms must be collectors or storehouses of knowledge for the development of core competencies leading to superior long-term performance.

\subsection{Organisation capital, corporate governance and corporate performance}

Corporate governance is related to organization capital in terms of direction, administration, and/or control of operating, investing and financing processes (Rodgers, Housel 2009). These concerns include protecting the rights and ensuring the equitable treatment of shareholders. The responsibilities of the board of directors include monitoring, disclosure and transparency. The board of directors can provide details about the functions that benefit the organization, its shareholders and its stakeholders.

A broadly positive relationship between intellectual capital and corporate performance has been found in several studies (Carpenter et al. 2001; Knight 1999; Lin et al. 2012; Narver, Slater 1990; Ting, Lean 2009). The mechanisms of corporate governance can alleviate or reduce agency costs, and effective corporate governance can significantly influence the organization's capacity, leading to changes in managerial ability and willingness to undertake organizational change (Zahra, Pearce 1989). Poor corporate governance leads to a decrease in growth and can damage the firm's intellectual capital, subsequently leading to poor operating performance (Dittmar, Mahrt-Smith 2007).

The role of the board of directors involves monitoring the firm's management. It can influence corporate value for its stakeholders by converting the stakes into goods and services (Abdullah 2004; Cotter et al. 1997; McConnell, Servaes 1995; Clarkson 1994; Williams 2000). Investors seek information in order to make informed decisions about a firm's growth opportunities. Both the quantity and quality of disclosure related to intellectual capital are linked to board size, the proportion of independent directors, and leadership, all governance attributes of these firms (Li, Harrison 2008). Directors utilize their expertise to improve the functioning of the firm by scanning the business environment, interpreting the information collected, and formulating strategies (Milliken, Vollrath 1991). Management needs to pay attention to the accumulation and development of internal knowledge with- 
in their organization (Edvinsson, Malone 1997; Bontis 2001; de Pablos 2002). Corporate governance can reduce agency costs and help to ensure the accumulation of appropriate innovation capital, as well as curtailing managerial propensities to pursue inefficient strategies (Tribo et al. 2007; Demsetz, Lehn 1985; Jensen, Meckling 1976; Lustig et al. 2011). This behaviour tends to generate higher creativity, stimulate innovation and ensure better quality decision-making. In addition, board functioning is closely related to organization capital and corporate performance (Zahra, Pearce 1989; Donaldson, Davis 1991, 1994). Given this close relationship, it is worth exploring whether the alignment between the board of directors and organization capital also enhances corporate performance in an emerging market, such as Taiwan's.

Independent directors can also bring to the board a wealth of expertise that is useful to management for deciding the direction the firm should take and to clarify its business strategies (Demirag et al. 2000; Abdullah 2004). There may be benefits to intellectual capital, such as reducing agency costs (Adjaoud et al. 2007) and providing expert advice and counsel (Daily, Dalton 1995). CEO duality also improves firm management, for example making it easier to determine the board's meeting agenda, and by strengthening the flow of information. These benefits are lacking when a firm adopts a non-dual structure. CEO duality assists with corporate development because of the individual's superior inside knowledge of the firm (Donaldson, Davis 1991, 1994). However, it is also known that managerial and directorial self-interest within the firm can compromise the best interests of investors (Fama, Jensen 1983).

Kamukama et al. (2011) contended that when a large number of seats on at the board are held by inside shareholders it encourages more thorough monitoring of management, giving greater incentive to maximize their own gains at the cost of other shareholders (Fama, Jensen 1983; Demsetz, Lehn 1985; Morck et al. 1988; Claessens et al. 2002).

Organization capital is an important factor that is embodied in organizational performance and is directly linked to corporate performance. Eisfeldt and Papanikolaou (2013) found that corporate governance accrued from organization capital and was necessary in order to ensure cash flow rights. Inside directors can use their influence to indirectly increase the firm's performance by corporate governance, and together talk with the firm's managers, to enforce the core competence at the mission of sustainable competitive advantage by directly conduit of information.

\subsection{Mediated associations between the board, organization capital and corporate performance}

The directors of board could be hold various directorships in different firms, they may have deliver their professional duties and information to improve organisation capital, board function are positive related to the corporate performance pass through organisation capital that directors transfer external knowledge, information and counseling for management to enforce their dynamic capacity in the accumulation of long run. Directors of board can transform resources into products or services though intellectual capital that is considered a strategic resource for mediation of the knowledge management processes in 
an organisation and create value for customers (Daud, Yusoff 2011; Kamukama et al. 2011). Hunt, Morgan (1995) indicated that organizational learning capability can create a competitive advantage through the use of new knowledge and complex resources, having positive effects on innovation and leading to improvements in corporate performance (Hsu, Fang 2009). Or its business strategy (Tseng et al. 2013), Black and Lynch (2005) directly included board function as a component of organization capital. We expect the mediating effect is dependent upon the environment status.

There has been little empirical investigation of the mediating effect of organization capital on the relationship between board function and corporate performance. Green organisation capital has an indirect impact on environmental product innovation through green social capital (Delgado-Verde et al. 2014), Hsu and Fang (2009) incorporated the mediating role of organization learning capability in their exploration of the relationship between intellectual capital and product development. Moeller (2009) and Wang (2011) developed different measurements to explore the linking and interaction of intangible and tangible factors and their effect on performance and the driving factors or key performance indicators causing lag in financial performance (Kaplan, Norton 2004). Organization capital mean simples that both shareholders and key talent (from management effort) have a cashflow claim. The value of the residual claim depends on the value of the organization capital (Eisfeldt, Papanikolaou 2013). Both innovation capital and process capital are mediators in the relationship between human capital and organization performance (Wang, Chang 2005). The indirect effects include a significantly positive relation between human capital, technological capital, process capital and business performance in the high-tech industry (Andreou et al. 2007). Kim et al. (2011) applied the structural path method to explore the relationship between $\mathrm{R} \& \mathrm{D}$, technology commercialization capability and performance with a mediating effect.

\section{Conceptual framework and hypothesis}

Analysis is performed at the governance-organization capital-performance level using data for Taiwanese listed firms. Figure 1 shows an outline of the conceptual framework used in the analysis, clarifying the different dimensions of the effect of board governance on corporate performance and its influence on CEO and management effort, our measure of corporate governance, through two channels. A direct channel stems from an organisational culture to create and store knowledge (Benevene, Cortini 2010). The directors of boards play an important roles on the information conduits and tie with social network in the managerial activities (Hsu, Fang 2009) with the top management inevitably affecting the management of intellectual capital as well as knowledge creation, because this culture is what provides the basis for an organisation's management (Lynn 2003). Ruiz-Mallorqui and Santana-Martin (2011) depict that the insiders have the means to influence corporate decisions in the Continental Europe, that the controlling shareholders give greater support to improve efficient in their organizational development, in contrast to the US-UK context, dominant directors tend to be insiders and consequently are actively involved in running the firm. 
Moreover, this framework also examines whether board function affects corporate performance via the mediating role of organization capital. Previous studies have emphasized the connection between intellectual capital and corporate governance and corporate performance. Organization capital, which is embedded in the organization and connected to its knowledge and capabilities, also covers organizational structure and process factors. The importance of organization capital in the production process is demonstrated by greater compensation and pay for improved performance (Lustig et al. 2011; Daud, Yusoff 2011). Corporate performance directly derives from the amount of organization capital, which includes process capital, innovation capital and relational capital used to generate knowledge value through synergy. The resulting shift in organisation capital accompanied by a change in the degree of dynamic capacity that characterizes the directors of board/managers in turn likely to affect the knowledge-based resource and subsequent performance of sustainable enterprises (Peppard, Rylander 2001) (these relations are indicated by arrows in Figure 1 b). If governance mechanisms alleviate agency problems, we would expect well-governed firms to have larger dynamic capacity and be more efficient in their organisational development, and thus receive higher managerial efficiency, profitability and fewer agencies cost. The mediating effect or indirect path of the influence of directors of board on corporate performance might stem from the effect the governance mechanisms on the CEO efforts. Directors of board focus on alleviating agency problem to the benefit of ownerships leads to higher profitability, higher effectiveness, and higher growth opportunities. In addition, perpetual values are strongly endorsed and rela-

a)

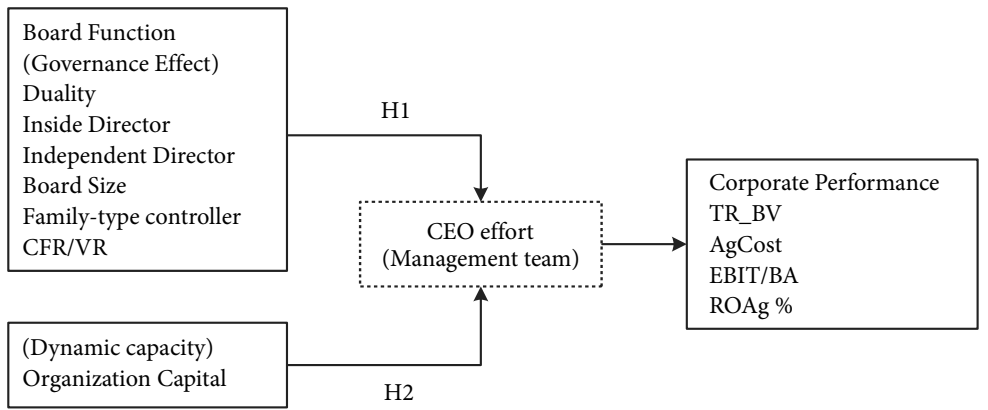

b)

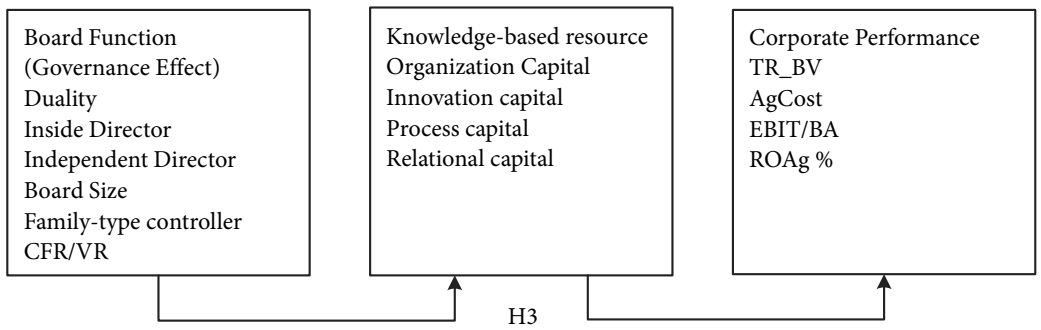

Fig. 1. a - direct path among of board function, organization capital and corporate performance; $\mathrm{b}$ - mediated effect between board function with corporate performance through organization capital 
tionships are highly valued with respect to internal organisation competence (transformation into capital) and the governance effect (board function), and this strong endorsement creates perpetual value leading to the attaining of a sustainable competitive advantage in today's complex business environment to provide a mechanism embodying the crucial benefits of exchange among investors in Taiwan.

Based on the discussion above, we arrive at the following hypothesis. Weak corporate governance generates deadweight loss, which in turn, leads to a higher cost of capital and worsens profitability (Albuquerque, Wang 2008; Garmaise, Liu 2005). It is also assumed that firms' investment decisions are made by controlling shareholders who can extract private benefits from outside investors at a cost. Chen et al. (2011) argued that controlling shareholders make investment decisions depending on the trade-off between the volatility of product efficiency and the amount of private benefit entrenchment. Thus, from the stewardship perspective, CEO duality is beneficial. It has been found to have a positive (Boyd 1995) and an insignificantly negative relation (Dalton et al. 1998). Our hypothesis supports the view of Boyd (1995).

This study assumes a direct link. It is thus argued that larger boards bring more diverse and vital resources making for more efficient decision-making. Thus a board size variable is employed test whether there is an association between small board size and improved firm performance (Eisenberg et al. 1998; Hermalin, Weisbach 2003; Kaymak, Bektas 2008). The results contradict those of Dalton et al. (1998) and Schweiger et al. (1986), who argued that larger sized boards can provide a wider range of solutions to achieve the goals on behalf of investors (Eisenhardt, Bourgeois 1988; Abeysekera 2010). The agency perspective considers there to be an alignment effect, and that independent directors will compromise the interests of investors which is associated with higher firm value and with better corporate decisions (Fama 1980; Fama, Jensen 1983; Byrd, Hickman 1992; Cotter et al. 1997; Anderson et al. 2004). In family controlled firms (whether controlled by a family, a family coalition or an individual), control of the board tends to be concentrated within the family, so the board is entitled to make more strategic decisions. Filatotchev et al. (2005) examined the effects of family control associated with performance measured in terms of accounting ratios, earnings per share and market-to-book value for publicly listed companies in Taiwan. Minichilli et al. (2010) found evidence supporting a hypothetically U-shaped relationship between the ratio of family control and firm performance. When family-control is central, high levels of ownership and low levels of family board representation can effectively decrease the agency problem and mitigate the separation of cash flow rights (Yeh et al. 2003). A dummy variable is used for family-controlled companies, such family control exceeds the critical control level in $76 \%$ of all companies, higher than the $50 \%$ documented by La Porta et al. (1998) and Claessens et al. (2000).

According to Stewart (1997), independent variables should be selected based on how performance is measured. Sveiby (2002) noted that different measurement methods have different advantages, and that the financial method of valuation, such as total production, agency costs, Earning before interest and tax to book Assets (EBIT/BA) and Return on Asset (ROA) growth, are also useful for stock market valuations. 
We argue that the functions have both consult and surveillance in the board that accompanies organisation capital will affect corporate performance through direct or mediating path of influence. A direct path stems from a change in the organisation capital accompanied by the significant and greater jointly determined management decisions with CEO effort that drills the dynamic capacity, hence affecting corporate performance. Therefore, depending on how control is allocated across different types of directors. We expect board to affect corporate performance in different ways. A mediating effect of the directors of board on corporate performance might stem from the effect of surveillance on the manager effort. Directors of board can alleviate agency problem to the benefit of organisation capital such that getting higher profitability, growth opportunities and effectiveness. The hypothesis is as follow:

H1: There is a positive relationship between board function and corporate performance.

H1a. There is a positive relation between a larger proportion of insider shareholders on the board, and lower agency costs, improved production efficiency and increased profitability.

H1b. CEO Duality is positively related to lower agency costs, improved production efficiency and increased profitability.

H1c. Firms that show greater improvements in profitability and efficiency have larger boards.

H1d. Firms that show greater improvements in profitability and efficiency have independent directors.

H1e. Family-typed controller of board has a negative effect on corporate performance and exacerbates the effects of the agency problem.

H1f. Cash flow to voting rights has a negative effect on corporate performance and exacerbates the effects of the agency problem.

Basically, organization capital describes what happens among the people within the company, how they are connected within the company and what stays when an employee leaves the company (Halim 2010). Previous studies offer their own classification of organization capital due to different measurements methods. In the framework proposed by Public (2004), innovation capital, process capital and relational capital are the three basic dimensions of organization capital, and these are also adopted in this study. Lin (2009), and Belo et al. (2014) explored innovation capital for the determination of asset risk premiums. Relational capital is essentially comprised of the knowledge embedded in the relationships with any stakeholder that has an influence on the organization (Ruta 2000). The performance variables selected include the EBIT/book value, ROAg and TR_BV. Firer and Williams (2003) found intellectual capital to be insignificantly related to ROA and ROE. Chen et al. (2005) provided empirical evidence that intellectual capital has a significant impact on profitability and capital efficiency (Maditinos et al. 2011). Process capital is the combined value of value-creating and non-value-creating processes (de Pablos 2002). This leads to the following hypothesis:

H2: There is a positive relationship between organisation capital and corporate performance. 
H2a. There is a positive relationship between innovation capital and total efficiency, ROAg, EBIT/BA and decreases in agency costs.

H2b. There is a positive relationship between process capital and total efficiency, ROAg, EBIT/BA and decreases in agency costs.

H2c. There is a positive relationship between relational capital and total efficiency, ROAg, EBIT/BA and decreases in agency costs.

Figure $1 \mathrm{~b}$ depicts four simple direct outcomes for organization capital-TR_BV, ROAg, EBIT/BA and AgCost in cases in which organization capital mediates the relationship between board function and corporate performance. Thus, the following hypotheses are formulated:

H3: Organization capital is positively related to corporate performance, incorporating corporate governance.

H3a. Innovation capital can improve productivity, profitability and reduce agency costs, incorporating board function.

H3b. Process capital can improve productivity, profitability and reduce agency costs, incorporating board function.

H3c. Relational capital can improve productivity, profitability and reduce agency costs, incorporating board function.

\section{Data and research design}

\subsection{Model specification}

The effect of board functioning on the estimated performance variables is investigated utilizing the following regression model:

$$
\begin{aligned}
& C P_{i t}=\alpha+\beta_{1} \text { Dual }_{i t}+\beta_{2} \text { Insdir }_{i t}+\beta_{3} \text { IndDir }_{i t}+\beta_{4} \text { CFR } / V_{i t}+ \\
& \beta_{5} \text { Fami }_{i, t}+\beta_{6} \text { Boardsize }_{i, t}+\beta_{7} \text { OGCA }_{i, t}+\varsigma_{t}+\varepsilon_{i, t},
\end{aligned}
$$

where Dual indicates CEO duality; Insdir represents inside directors; IndDir represents independent directors; Fami indicates family-type control; and CFR/VR is the ratio of cash flow rights to voting rights. Our main interest is the regression coefficient on OCGA $\left(\beta_{7}\right)$. Hypothesis 1 predicts that $\beta$ should be positive.

Equation (1) is estimated using the panel data method, however, we test which of the final specification methods, ordinary least squares (OLS), fixed effects (FE) or random effects (RE), are to be preferred, while controlling for the strict exogeneity assumption in the model. All of the different specification methods are estimated using lagged values as instruments. The results of the Hausman specification test and Breusch Pagan Lagrangian multiplier test never reject the null hypothesis of no endogeneity. The results show that, in most cases, individual effects are not significantly correlated to the explanatory variables, meaning that RE is the best way to model organization capital and board-level specifications.

The key outputs for the indirect path method are determined using the instrumental variables method. A mediated path contains a coefficient linking the control variable to the 
mediating variable and a coefficient linking the mediating variable to the outcome variable. One potential concern with the panel data with random effect regression on the Table 4 is that board function may be exogenous. Specifically, some unobserved determinants of corporate performance may also explain organisation capital, leading panel data estimates to be biased and inconsistent. In Table 6, we confront the issue of endogeneity using the two-stage instrumental variable estimations. We use all proxy variables for board function as an instrument for corporate performance. Instrumental variables estimates are consistent and unbiased when working with large samples; thus, we use the instrumental variables to estimate systems of simultaneous equations and to counteract bias due to measurement error. Some have used the partial least-squares (PLS) model to assess mediating effects (Bontis et al. 2007) for precisely this sort of data. In summary, TSLS is a method of data reduction designed to predict interrelations among the set of blocks considered (Sampson et al. 1989). In first-stage regressions, we predict organization capital (OGCA2) using board function along with other independent variables discussed earlier. The first-stage regression (unreported for the sake of space) shows that board function is good predictor of internal governance effect that mediating effect on the organization capital with performance using the first-stage fitted values for organization capital in the second-stage regression that the equation as follow:

$$
\begin{aligned}
& \tilde{A}_{i, t}=\lambda_{1} \text { Dual }_{i, t}+\lambda_{2} \text { Insdir }_{i, t}+\lambda_{3} \operatorname{IndDir}_{i, t}+\lambda_{4} \mathrm{CFR}_{/} \mathrm{VR}_{i, t}+ \\
& \lambda_{5} \text { Fami }_{i, t}+\lambda_{6} \text { Boardsize }_{i, t}+\mu_{i, t},
\end{aligned}
$$

where $\tilde{A}$ is an abbreviation of OGCA2, and OGCA is defined as in Equation (4). OGCA2 is adapted from the EP model which uses different measures from OGCA1, including the summation of innovation capital, relational capital and process capital; please refer to Equation (3).

$$
\mathrm{CP}_{i, t}=\theta_{0}+\theta_{1} \tilde{A}_{i, t}+\theta_{2} \mathrm{IVCA}_{i, t}+\theta_{3} \operatorname{ReCA}_{i, t}+\theta_{4} \operatorname{ProCA}_{i, t}+\varsigma .
$$

OGCA2 is adapted from the EP model which uses different measures from OGCA1, including the summation of innovation capital, relational capital and process capital; please see reference Equation (3), and $\varsigma$ is the error term. IVCA is included in Eq (2.b) because it may have a direct influence on corporate performance in addition to their indirect influence via OGCA2. ReCA and ProCA are also included as they may after corporate performance (see Delgado-Verde et al. 2014; Daud, Yusoff 2011; Bontis et al. 2007). We control for the potential effects of year-specific difference by using the panel data regression.

\subsection{Operational definitions}

\section{A. Organisation capital (OGCA)}

Process capital (ProCA) is defined as workflow, operational processes, know-how, business development planning, value system, cooperative culture and information and intelligence systems.

Innovation capital (IVCA) is defined as the intellectual property within an organization, which refers to a company's revolutionary capability, innovativeness, and potential build-up 
of new products and services, including patents, trademarks, know-how and copyrights on the output-side, and employees and organizational investments in new product development on the input-side (Ghazinoory et al. 2014).

Relational capital (ReCA) is classified as market intensity and marketing capability. Customer expectations and perceived value are not controllable, but the input cost of maintaining customer relationships is measurable. To improve customer related capital, a business may need to shorten the cycle time of its operating processes and develop highquality internal processes. The aggregated valuation method (aggregated model; hereafter AP model) is defined as follows ${ }^{2}$ :

$$
\text { OGCA1 }=\operatorname{ProCA}_{i, t}+\mathrm{IVCA}_{i, t}+\mathrm{ReCA}_{i, t} .
$$

Eisfeldt and Papanikolaou (2013) used the selling, general and administrative (SGA) expenditure as a proxy for organization capital because the largest component of SGA is typically labour related expenses. SGA expenses contain the component of employee spending to increase organization capital. This can include how resources are allocated for employee improvement incentives, expenses for internal communication systems and the dynamic capacity of knowledge-based systems (Lev, Radhaknishnan 2005; Lev 2001; Eosfeld, Papanikolaou 2013). The variable is formulated as follows:

$$
\mathrm{OGCA}_{i, t}=(1-\delta) \mathrm{OGCA}_{i, t-1}+\frac{\mathrm{SGA}_{i, t}}{g+\delta},
$$

where $\delta$ is the depreciation rate, assumed to be $15 \%(\mathrm{EP} \text { model })^{3}$; $\mathrm{g}$ is the average real growth rate of firm-level SGA expenditures ${ }^{4}$, which in our sample equals $10 \%$. Our measure of organization capital is adapted from Tronconi and Marzetti's (2011) EP model, which treated missing values in SGA expenses as zero, and is robust for a choice of between $10 \%$ and $50 \%$. To alleviate the industrial bias in variation in the composition of SGA expenditures across industries, OGCA is divided by total assets relative to their industry peers.

\section{B. Performance variables}

The performance measures computed are: (1) TR_BV (2) the ratio of accounting earnings before interest and taxes to book assets (EBIT/BA); and (3) ROA growth rate. In addition to providing more precise measures of performance, industry adjustments can be utilized to address econometric problems in cross-sectional analysis. Such problems can be caused by the mean reversion in accounting performance measures when the long-term mean values differ across industries.

Productivity describes how efficiency inputs are converted into outputs, and is calculated as the ratio of total revenue to total book value of assets, as reported in 2000-2011 annual reports. AgCosts acts as a proxy variable for agency problems, measured as operating expenses multiple the residuals which operating expense growth ratio minus annual sales growth ratio. Return on assets is the ratio of EBITDA over lagged total assets; the ROAg is the growth rate of ROA. 


\section{Board variables}

Duality of CEO (Dual) describes the situation in which one person serves as both chief executive and also chairperson of the board of directors (Donaldson, Davis 1991, 1994; Kim et al. 2009; Abeysekera 2010). This dummy variable is assigned a value of 1 when there is CEO duality dual and otherwise zero. From the perspective of agency, duality of CEO has a negative impact on board effectiveness (Fama, Jensen 1983; Jensen 1993), however, duality of CEO may help for performance when the board chairman have expertise in the focusing industrial fields operates in. the argument, taken together, indicate that the relationship between Dual and the corporate performance appears to be ambiguous.

Inside directors (InsDir) is the number of directors on the board who are substantial shareholders, officers of substantial shareholders, employed in an executive capacity by another group member, or a director paid by the parent company or foundation of the parent company. Inside directors possess superior amounts and quality of information allowing them to make superior decisions (Baysinger, Hoskisson 1990; Donaldson, Davis 1994). There is an apparent relationship between long-term investment (innovation capital) and inside directors (Baysinger et al. 1991) and a fair incentive for CEO compensation (Boyd 1994). The implication is that inside directors know the company intimately, have superior access to information and are therefore able to make more informed decisions (Nicholson, Kiel 2007).

Independent directors are defined as outside directors as directors who do not have an executive position in the firm, have not had such a position in the past, or are not related to an executive (Chen, S., Chen, I. 2012). We expect that corporate performance is likely to be more benefits for organisation capital with greater independent directors.

Board size is measured by the number of directors sitting on the board, including the board chairman, independent directors, managing directors and auxiliary chairman (Boeker 1992). Board size can affect the quality of manager's decision in the financial literature (Fama, Jensen 1983; Jensen 1993; Yermack 1996). We expect the smaller boards are more likely to mitigate the free rider problem and more efficiently management. However, Boone et al. (2007) found the more sophisticated boards help the investment decisions and the investment decision.

The family dummy (Fami) is a dummy variable that is assigned a value of 1 when family members are appointed to the board by the controlling family shareholders. We rely on the information from IPO prospectuses as well as news from the economic press to identify family members (including spouses or other relatives of the ultimate shareholder, even when they have a different family name).

The divergence in ultimate shareholder's cash flow rights to voting rights (CFR/VR). The data were obtained from the Taiwan Economic Journal (TEJ) database. Generally, the data showed a chain of control, where the ultimate owner exerts control over the firm through a multitude of links. The product of ownership is realized through the control chain. If the ratio of CFR to VR is less than 1 (CFR/VR), then there is a divergence between cash flow rights and voting rights.

The data on board of directors were obtained from the TEJ database. 


\subsection{Sample selection}

The sample used in this study is composed of data on 1,355 firms listed on the Taiwan Stock Exchange or Over-the-counter (OTC) trading of securities in Taiwan over the period 20012012. We start with 2001, the first year a consistent and unified set of accounting standards was applied for Taiwanese firms. There are several measures used in the empirical testing where comparability depends upon reliable accounting data. We eliminate observations with missing control variables, those for firms newly listed after 2001 and for firms that have been gone private during the period. We also eliminate events related to board restructuring such as spinoffs and takeovers. This selection process results in a final sample of 23,035 firm-year observations (1,355 firms) across several industries (see Table 1). Data were also collected from annual reports published by the firms (it should be noted that R\&D expenditure is not identified in either the TEJ or Taiwan Securities Exchange publicity bulletins). These firms are matched to the TEJ database to retrieve the Taiwan Securities Exchange Commission (TSEC) codes. Finally, we exclude initial public offering (IPO) firmyears and firm-years issuing equity in excess of $200 \%$ beginning-of-period equity stock. Table 1 presents the sample distribution data and Table 2 reports summary statistics for the variables used in our main tests.

The initial sample including the largest listed business groups in Taiwan, was divided utilizing the standard industrial classification (SIC) and the TSEC securities trading categories for the period from 2001 to 2012.

Table 1. Sample distribution by industry

\begin{tabular}{llclclcc}
\hline No. & Industry & Firms & Sampling ratio & No. & Industry & Firms & Sampling ratio \\
\hline 11 & Cement & 9 & $100 \%$ & 20 & Iron \& steel & 32 & $57.14 \%$ \\
\hline 12 & Food & 19 & $72.41 \%$ & 21 & Rubber & 10 & $72.73 \%$ \\
\hline 13 & Plastics & 21 & $82.61 \%$ & 22 & Automobiles & 7 & $50.00 \%$ \\
\hline 14 & Textiles & 53 & $96.67 \%$ & $\begin{array}{c}23,24, \\
30-36,42-49 \\
50-56,80-83, \\
89\end{array}$ & $\begin{array}{l}\text { Information \& } \\
\text { technology }\end{array}$ & 973 & $74.70 \%$ \\
& & & 25 & Construction & 30 & $60.00 \%$ \\
\hline 15 & $\begin{array}{l}\text { Electrical } \\
\text { machinery }\end{array}$ & 37 & $54.72 \%$ & 26 & Transportation & 18 & $57.69 \%$ \\
\hline 16 & $\begin{array}{l}\text { Electrical \& } \\
\text { cable }\end{array}$ & 15 & $55.56 \%$ & & & & \\
\hline 17 & Chemicals & 50 & $50.00 \%$ & 27 & Tourism & 6 & $67.00 \%$ \\
\hline 18 & Glass & 9 & $54.55 \%$ & 29 & Consumer goods & 15 & $73.33 \%$ \\
\hline 19 & Paper & 7 & $75.00 \%$ & 99 & Others & 44 & $100 \%$ \\
\hline
\end{tabular}

Notes: This table presents the industrial classification of 1,355 firms listed on the TSEC from 2001 to 2012. The sampling ratio for existing firms is calculated using all data divided by all firms listed in this industry. We use the balanced panel data to study the corporate governance, organization capital and the perpetual performance in the longitudinal analysis. First, we exclude the missing data, newly listed firms after 2001 and firms that have been gone private over the period 2001-2012. We also eliminate banks, utilization and various important events related to board restructuring, such as spinoffs and takeovers. 


\section{A. Descriptive statistics}

As shown in Table 2, TR_BV generates a moderate average performance estimate, with a mean of 0.801 and a median of 0.75 , whereas has the lower average performance, representative of the control of agency problems, with a mean of 0.65 and median of 2.04. The ratio EBIT/BA is 0.12 and ROAg is $2.00 \%$. The TR_BV ranges from 0.01 to 2.04, Agcosts ranges from 0.00 to 888.65 , EBIT/BA ranges from -47.73 to 11.39 and ROAg ranges from $-115.99 \%$ to $244.56 \%$. The variation in EBIT/BA and ROAg indicate the firms that have varied rates. A negative value indicates a negative dynamic capacity or declining market.

Panel B in Table 2 shows the descriptive statistics for board function. There were 1,355 firm-year observations in our final sample. The average board size was approximately 6.78 members, slightly less than the average board size of 7.5 for firms in the U.S. The large discrepancy between the maximum and mean size also reflects the fact that the stock exchange is primarily made up of small- and medium-sized companies. Family firms dominated in Taiwan throughout the entire period (Table 2, Panel B), and the cross-sectional variation was not large, with a standard deviation of 0.485 . That is, nearly $62 \%$ of listed companies were family controlled and 26\% (20\%) of the CEOs also acted as chairman of the board (Dual). The mean (median) persons for IndDir was 9.91 (3.00), indicative of more inside directors on the board. The mean (median) number of independent directors was 0.91 (1.00), less than for inside directors as shown in Table 2. The board of directors has a powerful counselling influence on CEO decisions. The table also show that the CFR/VR in the hands of the ultimate shareholders is 79.4 (mean) and 90.93 (median), less than the three largest shareholders in Spain ${ }^{5}$ (Ruiz-Mallorqui, Santana-Martin 2011).

The measure of organization capital by the aggregate model (OGCA1) is calculated from its three components of process capital, innovation capital and relational capital. Table 2, Panel C, show the mean (median) for OGCA1 which is 28.04(8.42). Checking IVCA, ProCA and ReCA, Panel C reveals a wide variation in ProCA with a mean of 12.21 and a standard deviation of 85.49 . The median value of IVCA is equal to 1.04, which suggests a right-skewed cross-sectional distribution of innovation capital (8.85). ProCA ranges from -186.0 to 19.11 , indicate a great deviation in business efficiency among the sample firms. There could be an increase in dynamic capacity as a consequence of the contribution from employee efforts including those of managers. The OGCA2 obtained from the EP model is calculated as general administration expenditure and also reveals wide variation and those data are similar to OGCA1. OGCA 2 has a mean (median) of 2.09 (1.27) and a standard deviation of 2.69. The standard deviation of ProCA is 7.77 times its mean, and the standard deviation of ReCA is 24.57 times its mean. Note that for both correlations, the median is lower, because the sample is largely dominated by R\&D firms (knowledge intensive). To deal with potential inference problems that arise due to the majority of R\&D firms in the sample, subsequent analysis considers subsamples that exclude some or all non-ICVA firms.

Klein (1998) suggested that when the absolute value of the coefficient of the skewness of the distribution of the variables is greater than 3, it can be regarded as extremely skewed, reaching a critical point when the absolute value of the coefficient of kurtosis is greater than 8. In these cases, it is necessary to consider what estimation method should be used. In this study, the coefficients of skewness for the observed variables range from 112.55 to -37.53 and the kurtosis values range from 18.36 to 259.49 as shown in Panel A of 
Table 2. Descriptive statistics

\begin{tabular}{|c|c|c|c|c|c|c|c|c|}
\hline Variable & Mean & Median & Minimum & Maximum & Std. Dev. & VIF & Skewness & Kurtosis \\
\hline \multicolumn{9}{|c|}{ Panel A. Corporate performance } \\
\hline TR_BV & 0.89 & 0.75 & -0.06 & 13.66 & 0.66 & & 2.78 & 18.36 \\
\hline AgCosts & 9.65 & 2.04 & 0.00 & 888.65 & 39.18 & & 12.11 & 189.46 \\
\hline EBIT/BA & 0.12 & 0.10 & -47.73 & 11.39 & 39.19 & & -37.53 & 259.49 \\
\hline ROAg & $2.0 \%$ & $0.52 \%$ & $-115.99 \%$ & $244.56 \%$ & 72.50 & & 112.55 & 24.47 \\
\hline \multicolumn{9}{|c|}{ Panel B. Board } \\
\hline Dual & 0.26 & 0.20 & 0.00 & 1.00 & 18.20 & 0.30 & -3.00 & 7.02 \\
\hline Insdir & 9.91 & 3.00 & 0.00 & 20.00 & 2.13 & 0.99 & 2.04 & 7.64 \\
\hline IndDir & 0.91 & 1.00 & 0.00 & 6.00 & 1.08 & 1.32 & 0.56 & -1.15 \\
\hline Board size & 6.78 & 7.00 & 3.00 & 28.00 & 2.30 & 2.17 & 2.28 & 10.22 \\
\hline Fami & $62.00 \%$ & $45.00 \%$ & $0.00 \%$ & $100 \%$ & 0.485 & 1.88 & 1.61 & -0.79 \\
\hline CFR/VR & 79.40 & 90.93 & 0.00 & 100.00 & 25.85 & 3.99 & -1.43 & 0.04 \\
\hline \multicolumn{9}{|c|}{ Panel C. Organization capital } \\
\hline OGCA1 & 28.04 & 8.42 & -184.21 & 115.68 & 26.61 & 0.19 & 14.27 & 398.79 \\
\hline OGCA2 & 2.09 & 1.27 & 0.00 & 49.96 & 2.69 & 0.11 & 5.15 & 45.12 \\
\hline IVCA & 1.04 & 0.26 & 0.00 & 50.00 & 3.43 & 4.84 & 8.85 & 99.67 \\
\hline ProCA & 12.21 & 4.64 & -186.00 & 19.11 & 94.11 & 1.77 & 18.83 & 470.66 \\
\hline $\mathrm{ReCA}$ & 3.48 & 1.29 & 0.29 & 7.89 & 85.49 & 1.77 & 14.27 & 126.31 \\
\hline \multicolumn{9}{|c|}{ Panel D. Control variables } \\
\hline Firm scale & 15.61 & 15.43 & 12.46 & 20.29 & 1.26 & & & \\
\hline Debt ratio & $9.18 \%$ & $7.14 \%$ & $0.4 \%$ & $92.53 \%$ & 8.63 & & & \\
\hline
\end{tabular}

Notes: Table 2 represents the summary statistics for the estimates of the (A) corporate performance (B) board (C) organization capital and (D) control variables. Sample of all firms traded on the Taiwan Stock Exchange and OTC, excluding banks, insurance and purely financial companies, for the years 2001 through 2012; the table reports the results of 23,035 year-observations, total 276,420. The mean, median, standard deviation, minimum and maximum of the variables are used in this analysis. The dependent variable is TR_BV, AgCosts, EBIT/BA and ROAg. TV_BV is calculated as the ratio of total revenue to total book value of assets, AgCosts measured as operating expenses multiple the residuals which operating expense growth ratio minus annual sales growth ratio. ROAg is the next ROA minus the current ROA to divide the current ROA. Dual is equal to one if the chairman of the board and the $\mathrm{CEO}$ of the company are the same person. InsDir was measured by calculating the percentage of total shares held by the insider holding shares who owns more than $5 \%$ of a corporate or an officer or director. IndDir measure defines independent directors as outside board members who are appointed prior to the current CEO. Board size is measured as the number of directors sitting on the board. Family Dummy (Fami) is a dummy variable that takes a value of 1 when the controlling family shareholders influence the composition of the board by appointing family members. CFR/VR is cash flow rights to voting rights; please see reference notation. Board Size is the number of board members. For OGCA1 and OGCA2, please refer to Eq. (3) and Eq. (4). The multicollinearity test gives the VIF value.

Table 1. The estimation results show a non-normal distributionl therefore, the RE TSLS models are used with the panel data. To further examine the results of no multi-colinearity in measurement of the Variance Inflation Factor (VIF) for each independent variable estimated in this study. We find that the average VIF is below 5 which is the threshold value, indicating whether a multi-colinearity problem is inclined to occur. Therefore, the multi-colinearity is not a problem in our sample. 


\section{B. Correlation: direct path and mediated path}

We posit and test for evidence of a direct link (path) between organization capital, board function and corporate performance, and an indirect link, in which directors of the board play a counselling role. Organization capital is influenced by dynamic capacity and that, in turn, influences functional effectiveness, firm performance and alleviation of agency problems (Čiutienè et al. 2015). Table 3, Panel A shows results for organization capital measured by the direct path, the Pearson correlation coefficients are above the diagonal, the Spearman correlation coefficients are below the diagonal with the corporate performance. The Pearson (Spearman) correlation is about 0.337 (0.119) for TR_BV, about $-0.07(-0.011)$ for AgCosts, about -0.024 (-0.133) for EBIT/BA (significant at the 0.001 level or better), but for ROAg shows an insignificant correlation of about 0.001 (0.006). OGCA1 is an aggregate model for the summation of innovation capital, process capital and relational capital. Innovation capital is negatively correlated with agency costs, which is consistent with the view that firms with a weak internal governance mechanism tend to have less R\&D input. Relational capital inversely measures the improvement in quality of organization capital. The negative correlations between AgCosts and EBIT/BA, although only suggestive of the underlying relation, indicate that, in firms with less $R \& D$ expenditure, added economic value is associated with improvement in intangible assets and physical capital (Eisfeldt, Papanikolaou 2013). As expected, the three components are significantly and positively correlated to organization capital and each other.

[OGCA2, performance] is the direct path coefficient that is attributable to the direct path. The direction of OGCA2 is similar to OGCA1 although it measures is adapted by EP model, the [OGCA2, EBIT/BA] are significantly negatively related to performance which different than for OGCA1.

The data in Panel B and Panel C of Table 3 show the direct and mediated paths in terms of board function. The mediated correlation and labelled coefficient captures the portion of correlation between board function and organization capital that is attributable to mediating effects.

The value of [Dual, OGCA] is about 0.19 , attributable to the direct path, but [Dual, performance] is only significantly correlated with TR_BV, hence, duality has a partially direct effect on effectiveness, and a partially mediating effect on the performance variables through organization capital. For both InsDir and IndDir, the direct path coefficient is about $21 \%(21 \%)$ and $6.5 \%(3.0 \%)$, and the mediating path coefficient is about $19.5 \%(12.8 \%)$. Both the direct and mediating path are highly significant. Across our four measures of corporate performance, all direct and mediating paths are reliably nonzero, and the direct link is substantially more important than the mediated link. The coefficient is insignificantly correlated, with [CFR/VR, OGCA] having a value of $0.848(0.246)$, however, [CFR/VR, performance] means that direct path is significantly correlated to TR_BV, AgCost and EBIT/BA. Table 3 reveals that the correlation coefficients are moderate and don't violate the assumption of independence between explanatory variables, and no multi-colinearity appear to be a problem in our models. 
Table 3. Correlation coefficient matrix

\begin{tabular}{lccccccccc}
\hline \multicolumn{1}{c}{ Panel A. Organization capital and corporate performance } \\
\hline & $(1)$ & $(2)$ & $(3)$ & $(4)$ & $(5)$ & $(6)$ & $(7)$ & $(8)$ & $(9)$ \\
\hline TR_BV (1) & 1.000 & -0.146 & 0.078 & 0.005 & 0.119 & 0.167 & 0.151 & 0.155 & -0.001 \\
& & $(0.000)$ & $(0.000)$ & $(0.253)$ & $(0.000)$ & $(0.000)$ & $(0.000)$ & $(0.000)$ & $(0.474)$ \\
\hline AgCosts (2) & -0.326 & 1.000 & -0.068 & 0.0001 & -0.011 & 0.033 & -0.046 & -0.010 & -0.003 \\
& $(0.000)$ & & $(0.000)$ & $(0.479)$ & $(0.081)$ & $(0.000)$ & $(0.018)$ & $(0.100)$ & $(0.334)$ \\
\hline EBIT/BA (3) & 0.275 & -0.245 & 1.000 & 0.000 & -0.133 & -0.027 & 0.011 & -0.174 & -0.006 \\
& $(0.000)$ & $(0.000)$ & & $(0.494)$ & $(0.000)$ & $(0.000)$ & $(0.000)$ & $(0.000)$ & $(0.235)$ \\
\hline ROAg (4) & 0.030 & 0.007 & 0.036 & 1.000 & 0.006 & -0.009 & -0.003 & 0.000 & 0.000 \\
& $(0.000)$ & $(0.189)$ & $(0.000)$ & & $(0.479)$ & $(0.123)$ & $(0.331)$ & $(0.494)$ & $(0.497)$ \\
\hline OGCA1 (5) & 0.337 & -0.070 & -0.024 & 0.001 & 1.000 & 0.149 & 0.062 & 0.151 & 0.666 \\
& $(0.000)$ & $(0.000)$ & $(0.001)$ & $(0.473)$ & & $(0.000)$ & $(0.000)$ & $(0.000)$ & $(0.000)$ \\
\hline OGCA2 (6) & 0.209 & 0.143 & 0.112 & -0.058 & 0.221 & 1.000 & -0.026 & 0.737 & 0.666 \\
& $(0.000)$ & $(0.000)$ & $(0.000)$ & $(0.000)$ & $(0.000)$ & & $(0.001)$ & $(0.000)$ & $(0.000)$ \\
\hline IVCA (7) & 0.216 & -0.208 & 0.018 & -0.003 & 0.127 & 0.013 & 1.000 & 0.057 & -0.011 \\
& $(0.000)$ & $(0.000)$ & $(0.011)$ & $(0.331)$ & $(0.000)$ & $(0.054)$ & & $(0.000)$ & $(0.079)$ \\
\hline ProCA (8) & 0.445 & -0.074 & -0.174 & 0.000 & 0.719 & 0.284 & 0.057 & 1.000 & -0.012 \\
& $(0.000)$ & $(0.000)$ & $(0.000)$ & $(0.476)$ & $(0.000)$ & $(0.000)$ & $(0.000)$ & & $(0.067)$ \\
\hline ReCA (9) & 0.022 & 0.026 & -0.006 & 0.000 & 0.534 & 0.039 & -0.011 & -0.012 & 1.000 \\
& $(0.000)$ & $(0.000)$ & $(0.235)$ & $(0.497)$ & $(0.000)$ & $(0.000)$ & $(0.079)$ & $(0.067)$ & \\
\hline
\end{tabular}

Panel B. Board function and organization capital

\begin{tabular}{llllllllllc}
\hline & $(5)$ & $(6)$ & $(10)$ & $(11)$ & $(12)$ & $(13)$ & $(14)$ & $(15)$ & $(16)$ & $\begin{array}{c}\text { Debt } \\
(17)\end{array}$ \\
\hline OGCA1 & 1.000 & 0.149 & -0.190 & 0.210 & 0.065 & 0.010 & 0.064 & 0.002 & 0.111 & 0.120 \\
$(5)$ & & $(0.000)$ & $(0.001)$ & $(0.000)$ & $(0.030)$ & $(0.000)$ & $(0.004)$ & $(0.913)$ & $(0.000)$ & $(0.000)$ \\
\hline OGCA2 & 0.221 & 1.000 & 0.010 & -0.032 & 0.054 & -0.025 & -0.068 & -0.005 & 0.112 & 0.003 \\
$(6)$ & $(0.000)$ & & $(0.553)$ & $(0.000)$ & $(0.000)$ & $(0.001)$ & $(0.000)$ & $(0.246)$ & $(0.000)$ & $(0.000)$ \\
\hline Dual (10) & 0.009 & 0.009 & 1.000 & -0.016 & 0.003 & -0.002 & -0.027 & -0.016 & -0.002 & -0.030 \\
& $(0.001)$ & $(0.553)$ & & $(0.271)$ & $(0.187)$ & $(0.898)$ & $(0.066)$ & $(0.280)$ & $(0.898)$ & $(0.048)$ \\
\hline Insdir (11) & 0.210 & 0.148 & -0.062 & 1.000 & -0.260 & 0.582 & 0.107 & 0.007 & -0.011 & -0.305 \\
& $(0.000)$ & $(0.000)$ & $(0.000)$ & & $(0.000)$ & $(0.000)$ & $(0.000)$ & $(0.203)$ & $(0.453)$ & $(0.000)$ \\
\hline IndDir (12) & 0.030 & -0.098 & 0.003 & -0.286 & 1.000 & 0.105 & -0.126 & -0.077 & -0.121 & -0.078 \\
& $(0.043)$ & $(0.000)$ & $(0.851)$ & $(0.000)$ & & $(0.000)$ & $(0.000)$ & $(0.000)$ & $(0.000)$ & $(0.000)$ \\
\hline Board size & 0.114 & -0.221 & -0.020 & 0.362 & 0.184 & 1.000 & -0.064 & -0.194 & 0.341 & -0.038 \\
$(13)$ & $(0.000)$ & $(0.000)$ & $(0.262)$ & $(0.000)$ & $(0.000)$ & & $(0.000)$ & $(0.000)$ & $(0.000)$ & $(0.011)$ \\
\hline Fami (14) & 0.044 & 0.204 & 0.341 & 0.136 & -0.128 & -0.093 & 1.000 & -0.034 & 0.288 & 0.014 \\
& $(0.004)$ & $(0.000)$ & $(0.000)$ & $(0.000)$ & $(0.000)$ & $(0.000)$ & & $(0.022)$ & $(0.000)$ & $(0.336)$ \\
\hline CFR/VR & 0.003 & -0.005 & -0.016 & -0.221 & -0.098 & -0.221 & 0.204 & 1.000 & 0.225 & 0.116 \\
$(15)$ & $(0.848)$ & $(0.246)$ & $(0.280)$ & $(0.000)$ & $(0.000)$ & $(0.000)$ & $(0.000)$ & & $(0.000)$ & $(0.000)$ \\
\hline Firmsize & 0.113 & -0.053 & -0.121 & 0.171 & -0.120 & 0.171 & 0.288 & 0.204 & 1.000 & 0.099 \\
$(16)$ & $(0.000)$ & $(0.000)$ & $(0.000)$ & $(0.000)$ & $(0.000)$ & $(0.000)$ & $(0.000)$ & $(0.000)$ & & $(0.000)$ \\
\hline
\end{tabular}


End of Table 3

\begin{tabular}{lcccccc}
\hline \multicolumn{7}{c}{ Panel C. Board function and corporate performance } \\
\hline & $\begin{array}{c}\text { Dual } \\
(10)\end{array}$ & $\begin{array}{c}\text { Insdir } \\
(11)\end{array}$ & $\begin{array}{c}\text { IndDir } \\
(12)\end{array}$ & $\begin{array}{c}\text { Boardsize } \\
(13)\end{array}$ & $\begin{array}{c}\text { Fami } \\
(14)\end{array}$ & $\begin{array}{c}\text { CFR/VR } \\
(15)\end{array}$ \\
\hline TR_BV (1) & 0.049 & -0.195 & 0.128 & -0.076 & -0.122 & -0.066 \\
& $(0.001)$ & $(0.000)$ & $(0.000)$ & $(0.000)$ & $(0.000)$ & $(0.000)$ \\
\hline AgCosts (2) & -0.030 & -0.103 & 0.045 & -0.062 & -0.029 & 0.009 \\
& $(0.047)$ & $(0.000)$ & $(0.000)$ & $(0.000)$ & $(0.000)$ & $(0.121)$ \\
\hline EBIT/BA (3) & -0.016 & -0.023 & 0.133 & 0.054 & -0.038 & -0.068 \\
& $(0.272)$ & $(0.002)$ & $(0.000)$ & $(0.000)$ & $(0.000)$ & $(0.000)$ \\
\hline ROAg & 0.011 & 0.251 & 0.041 & -0.034 & -0.006 & 0.017 \\
& $(0.458)$ & $(0.000)$ & $(0.005)$ & $(0.025)$ & $(-0.708)$ & $(0.258)$ \\
\hline
\end{tabular}

Notes: The table reports the correlation matrix, The Pearson's-coefficients are above the diagonal and the Spearman rank coefficients are below the diagonal, reported are coefficients and p-values (in parentheses) from correlations tests, the statistical significance at the $1 \%, 5 \%$, and $10 \%$ levels, respectively. The definitions and data sources for the variables are outlined in the Section 4.

\section{Results and findings}

\subsection{Random effects in the direct path}

In Table 4, OGCA1 and OGCA2, we report the results for the relationship between corporate performance, and the following governance measures respectively. Duality, independent directors, insider director, board size, family-type controller and cash flow to vote rights. We report on four measures of corporate governance: relation of total revenue to book value of assets, the relation of operating expenses to operating costs, EBIT divided by the book value and ROA growth rate. The results presented in Table 4 are consistent with our expectations. The coefficients for OGCA1 are significantly positive for TR_BV (0.037), EBIT/BA (0.584), but are negative for AgCosts (-0.053) and ROAg (-0.115), as shown in Panel A, Table 4. This indicates that the efficiency of organization capital does not increase due to management effort or concern with long-term corporate value. Knowledge-based resources are reflected in terms of profitability, as is observed among the board of directors. The aggregate model sums up innovation capital, process capital and customer related capital, showing lower relations with agency problems.

In column (2), we examine how organization capital influences agency problehms related to board function and the direct governance effect during the period from 2001-2012. Because of the different nature of organization capital between the two models, they are analysed separately. Estimating two separate regressions also avoids the use of interaction variables and simplifies the interpretation of the results. The significantly negative coefficient on AgCosts suggests an association between organization capital and agency cost for firms with board functions. This means that organization capital is significantly less sensitive to agency problems in random effects in the long-run. However, the EP model of OGCA2 shows an insignificantly negative relation to agency cost. It could be argued that the board of directors exercise poor monitoring mechanisms because they lack incentives due to ownership dispersion, rather than because they seek the tunnelling objective. 
Table 4. Board function, organization capital and corporate performance

\begin{tabular}{|c|c|c|c|c|}
\hline $\begin{array}{c}\text { Panel A } \\
\text { Variables }\end{array}$ & $\begin{array}{c}\text { TR_BV } \\
\text { Total production }\end{array}$ & $\begin{array}{l}\text { AgCosts } \\
\text { Agent cost }\end{array}$ & $\begin{array}{c}\text { EBIT/BA } \\
\text { EBIT /book value }\end{array}$ & $\begin{array}{c}\text { ROAg } \\
\text { ROA growth \% }\end{array}$ \\
\hline Constant & $\begin{array}{l}1.082^{* * *} \\
(4.232)\end{array}$ & $\begin{array}{l}8.968^{* * *} \\
(5.711)\end{array}$ & $\begin{array}{l}0.360^{* * *} \\
(9.063)\end{array}$ & $\begin{array}{l}2.590^{* * *} \\
(5.405)\end{array}$ \\
\hline $\begin{array}{l}\text { OGCA1 } \\
\text { Organization Capital }\end{array}$ & $\begin{array}{l}0.037^{* * *} \\
(3.010)\end{array}$ & $\begin{array}{l}-0.007^{* * *} \\
(-3.756)\end{array}$ & $\begin{array}{l}0.584^{* * *} \\
(5.045)\end{array}$ & $\begin{array}{l}-0.115^{* * *} \\
(-3.244)\end{array}$ \\
\hline $\begin{array}{l}\text { Dual } \\
\text { Director Duality for CEO }\end{array}$ & $\begin{array}{l}0.312^{* * *} \\
(3.363)\end{array}$ & $\begin{array}{l}-0.053^{* *} \\
(-2.009)\end{array}$ & $\begin{array}{l}-2.717 \\
(-1.284)\end{array}$ & $\begin{array}{c}0.342 \\
(0.705)\end{array}$ \\
\hline $\begin{array}{l}\text { Insdir } \\
\text { Inside Director }\end{array}$ & $\begin{array}{l}-0.029^{* * *} \\
(0.003)\end{array}$ & $\begin{array}{l}-0.123 \\
(-0.618)\end{array}$ & $\begin{array}{l}-0.006^{*} \\
(-1.820)\end{array}$ & $\begin{array}{l}0.480^{* * *} \\
(3.375)\end{array}$ \\
\hline $\begin{array}{l}\text { IndDir } \\
\text { Independent Director }\end{array}$ & $\begin{array}{l}0.026^{* * *} \\
(4.822)\end{array}$ & $\begin{array}{l}-0.391 \\
(-1.159)\end{array}$ & $\begin{array}{l}0.030^{* * *} \\
(5.565)\end{array}$ & $\begin{array}{c}0.679^{* *} \\
2.345\end{array}$ \\
\hline $\begin{array}{l}\text { CFR/VR } \\
\text { Cash flow to Vote Right }\end{array}$ & $\begin{array}{l}-0.001^{* * *} \\
(-2.652)\end{array}$ & $\begin{array}{c}0.014 \\
(1.122)\end{array}$ & $\begin{array}{l}-0.001^{* * *} \\
(-1.742)\end{array}$ & $\begin{array}{l}-0.002 \\
-0.622\end{array}$ \\
\hline Board size & $\begin{array}{l}-0.012^{* * *} \\
(0.003)\end{array}$ & $\begin{array}{l}-0.313^{*} \\
(-1.748)\end{array}$ & $\begin{array}{l}0.007^{* * *} \\
(2.305)\end{array}$ & $\begin{array}{l}0.873^{*} \\
(1.720)\end{array}$ \\
\hline $\begin{array}{l}\text { Fami } \\
\text { Family-type Controller }\end{array}$ & $\begin{array}{l}-0.112^{* * *} \\
(-10.46)\end{array}$ & $\begin{array}{l}1.967^{* *} \\
(2.931)\end{array}$ & $\begin{array}{l}0.018^{*} \\
(1.667)\end{array}$ & $\begin{array}{c}0.169 \\
(0.844)\end{array}$ \\
\hline Adj-R Square & 0.376 & 0.366 & 0.687 & 0.383 \\
\hline Hausman test & $\begin{array}{c}22.50 \\
(0.000)\end{array}$ & $\begin{array}{c}17.01 \\
(0.000)\end{array}$ & $\begin{array}{c}4.536 \\
(0.605)\end{array}$ & $\begin{array}{l}46.965 \\
(0.000)\end{array}$ \\
\hline $\begin{array}{c}\text { Panel B } \\
\text { Constant }\end{array}$ & $\begin{array}{l}1.129^{* * *} \\
(4.429)\end{array}$ & $\begin{array}{c}10.348^{* * \star} \\
(5.366)\end{array}$ & $\begin{array}{l}0.116^{\star * *} \\
(4.355)\end{array}$ & $\begin{array}{l}2.522^{* * *} \\
(5.349)\end{array}$ \\
\hline $\begin{array}{l}\text { OGCA2 } \\
\text { Organization Capital }\end{array}$ & $\begin{array}{l}0.001^{* * *} \\
(5.03)\end{array}$ & $\begin{array}{l}-0.004 \\
(-1.455)\end{array}$ & $\begin{array}{l}0.001^{* * *} \\
(7.36)\end{array}$ & $\begin{array}{c}0.002 \\
(0.250)\end{array}$ \\
\hline $\begin{array}{l}\text { Dual } \\
\text { Director Duality for CEO }\end{array}$ & $\begin{array}{l}0.312^{* * *} \\
(3.033)\end{array}$ & $\begin{array}{l}-0.477 \\
(-1.288)\end{array}$ & $\begin{array}{c}0.564 \\
(0.730)\end{array}$ & $\begin{array}{c}0.342 \\
(0.704)\end{array}$ \\
\hline $\begin{array}{l}\text { Insdir } \\
\text { Inside Director }\end{array}$ & $\begin{array}{l}-0.028^{* * *} \\
(-8.574)\end{array}$ & $\begin{array}{l}-0.143 \\
(-0.718)\end{array}$ & $\begin{array}{l}-0.007^{* * *} \\
(-20.36)\end{array}$ & $\begin{array}{l}-0.110^{*} \\
(-1.833)\end{array}$ \\
\hline $\begin{array}{l}\text { IndDir } \\
\text { Independent Director }\end{array}$ & $\begin{array}{l}0.035^{* * *} \\
(6.330)\end{array}$ & $\begin{array}{l}-0.235 \\
(-0.701)\end{array}$ & $\begin{array}{l}0.028^{* * \star} \\
(5.297)\end{array}$ & $\begin{array}{c}0.092 \\
(0.972)\end{array}$ \\
\hline $\begin{array}{l}\text { CFR/VR } \\
\text { Cash flow to Vote Right }\end{array}$ & $\begin{array}{l}-0.001^{*} \\
(-1.885)\end{array}$ & $\begin{array}{c}0.017 \\
(1.353)\end{array}$ & $\begin{array}{l}-0.001^{*} \\
(-1.821)\end{array}$ & $\begin{array}{l}-0.002 \\
(-0.658)\end{array}$ \\
\hline Board size & $\begin{array}{l}-0.013^{* * *} \\
(-4.334)\end{array}$ & $\begin{array}{l}-0.336^{*} \\
(-1.878)\end{array}$ & $\begin{array}{l}0.006^{* *} \\
(2.008)\end{array}$ & $\begin{array}{c}-0.074 \\
(-1.363)\end{array}$ \\
\hline $\begin{array}{l}\text { Fami } \\
\text { Family-type Controller }\end{array}$ & $\begin{array}{l}-0.124^{* * *} \\
(-11.55)\end{array}$ & $\begin{array}{l}1.703^{* * *} \\
(2.595)\end{array}$ & $\begin{array}{l}-1.821 \\
(0.017)\end{array}$ & $\begin{array}{c}0.100 \\
(0.503)\end{array}$ \\
\hline Adj-R Square & 0.640 & 0.119 & 0.434 & 0.318 \\
\hline Hausman test & $\begin{array}{l}6.064 \\
(0.416)\end{array}$ & $\begin{array}{l}7.544 \\
(0.273)\end{array}$ & $\begin{array}{c}4.046 \\
(0.670)\end{array}$ & $\begin{array}{l}49.05 \\
(0.000)\end{array}$ \\
\hline
\end{tabular}

Notes: Organization capital is measure as aggregated model and EP model, aggregated model is the sum of relational capital, process capital and innovation capital and EP model is described by Eq. (4). The dependent variable is TR_BV, AgCosts, EBIT/BA and ROAg. TV_BV is calculated as the ratio of total revenue to total book value of assets, AgCosts measured as operating expenses multiple the residuals which operating expense growth ratio minus annual sales growth ratio. Return on assets is the ratio of EBITDA over lagged total assets; the ROAg is the growth rate of ROA. Dual is equal to one 
if the chairman of the board and the CEO of the company are the same person. InsDir was measured by calculating the percentage of total shares held by the insider holding shares who owns more than $5 \%$ of a corporate or an officer or director. IndDir measure defines independent directors as outside board members who are appointed prior to the current CEO. Board size is measured as the number of directors sitting on the board. Family Dummy (Fami) is a dummy variable that takes a value of 1 when the controlling family shareholders influence the composition of the board by appointing family members. CFR/VR is cash flow rights to voting rights; please see reference notation. Board Size is the number of board members. Hausman test results reject the null hypothesis and determine the presence of random effects. If the results reject the null hypothesis, it is not necessary to test for random effects.

This explanation would predict a similar finding for non-innovation capital; see panel B, Table 5. The same model is used with variable measurement to estimate the influence of organization capital on reducing agency costs. There is no significant association between organization capital and agency cost, because non-innovation capital with CEO effort leads to a relatively weaker position making earnings manipulation more likely in order to entrench private benefits.

Given the evidence on board function, which have a more aggressive counselling and transmission of knowledge for information inflow, we find significant effects for almost all of the performance. The higher number of inside directors means better functioning for organization capital due to enforcement of management effort and offering of knowledgebased resources to the firm. Inside directors are more likely to act as consultants and friendly instructors to strengthen the about core competence of the firm and thus corporate performance as well as restraining managerial expropriation. Independent directors mean greater board independence and more effective governance effectiveness, which in turn encourages counselling functions to let firms develop better organization capital.

Results for the aggregate OGCA1 model as shown in column (3), there is a positive association with EBIT/BA at the $1 \%$ level. The EP model of OGCA2 also shows a significantly positive relation to EBIT/BA. The results contribute to our understanding of the EP model in terms of explaining the variations in time-series analysis. The coefficient is only 0.001 . Higher time-variation implies a dynamic capacity for enforcing profitability form a longitudinal view.

The Hausman test is carried out to consider the random effect estimates for inferences on panel data. There is a significantly negative relation between family-control and TR_BV $(-0.112, t=-10.46$ and $-0.124, t=-11.55)$ and an insignificant relation with $\operatorname{ROAg}(0.169$, $t=0.844 ; 0.100, t=0.503)$. As noted above, if family-control anticipates the effect of corporate governance on agency problems, the aggregate model does not take into account the endogeneity of the relationship between board function, performance and organization capital, so family-control will not be significantly related to agency costs in management effort that controls SGA expenditure. The findings are consistent with those of Bontis et al. (2000), who also found that organization capital influences corporate performance, although not all elements contribute to the efficiency. By demonstrating that cross-sectional variation in the effect of board function on corporate performance is consistent with the a priori theoretical prediction, we can further clarify the organization capital (results are shown in Table 5) is affected by board function. 


\subsection{Robustness: when FIRMS have R\&D inputs but focus on the relationship with customers}

In theory, we need a measure of organization capital without governance factors. If a firm does not have agency problems due to shareholder governance, then the observed total productivity, agency costs, EBIT/BV and ROA growth are not a good way to measure true organization capital. The second hypothesis is tested through regression (5). Control variables such as firm scale and debt ratio are included to measure the relationship between organization capital and corporate performance.

For firm with R\&D inputs:

$$
\begin{aligned}
& \mathrm{CP}_{j, t}=\varphi_{0}+\varphi_{1} \mathrm{OGCA}_{j, t}+\varphi_{2} \mathrm{IVCA}_{j, t}+\varphi_{3} \text { ProCA }_{j, t}+\varphi_{4} \text { ReCA }_{j, t}+ \\
& \varphi_{5} \text { FirmScale }_{j, t}+\varphi_{6} \mathrm{D}_{j, t}+\varepsilon ; \\
& \mathrm{CP}_{j, t}=\widehat{\varphi}_{0}+\widehat{\varphi}_{1} \mathrm{OGCA}_{j, t}+\widehat{\varphi}_{5} \text { FirmScale }_{j, t}+\widehat{\varphi}_{6} \mathrm{D}_{j, t}+\varepsilon .
\end{aligned}
$$

With no R\&D inputs, the equation is as follows:

$$
\begin{aligned}
& \mathrm{CP}_{j, t}=\hat{\varphi}_{0}+\hat{\varphi}_{1} \mathrm{OGCA}_{j, t}+\hat{\varphi}_{3} \text { ProCA }_{j, t}+\hat{\varphi}_{4} \operatorname{ReCA}_{j, t}+ \\
& \hat{\varphi}_{5} \text { FirmScale }_{j, t}+\hat{\varphi}_{6} \mathrm{D}_{j, t}+\varepsilon ; \\
& \mathrm{CP}_{j, t}=\tilde{\varphi}_{0}+\tilde{\varphi}_{1} \mathrm{OGCA1}_{j, t}+\tilde{\varphi}_{5} \text { FirmScale }_{j, t}+\tilde{\varphi}_{6} \mathrm{D} \%+\varepsilon .
\end{aligned}
$$

The results are sorted into two groups depending on whether R\&D input is less than or greater than zero. We find that there are 986 firms in the sample with innovation capital and 359 without. The results for the baseline models are provided in Table 5. As shown in the table, the coefficients for OGCA2 are positive in all regressions and statistically significantly for TR_BV, EBIT/BA (see Panel A) and EBIT/BA (see Panel B).

The extent of the influence of organization capital on a firm is examined in two ways. First, we discriminate between two groups based on with $\mathrm{R} \& \mathrm{D}$ input (innovation capital) and zero R\&D input (non-innovation capital). Firms with a higher ratio for the aggregate model of OGCA1 to TR_BV (EBIT/BA) have 4\% (56.1\%) more average revenue (value) per year in R\&D input than those with a lower ratio (coefficient of TR_BV is $0.7 \%$ and of EBIT/BA is $18.9 \%$ ). This result indicates that firms with greater R\&D input tend to have more intangible assets. We find that OGCA1 is significantly negatively related to agency cost in that has innovation capital (as can be seen in panel A of Table 5). However, without innovation capital, the relationship is insignificant. It is interesting that innovation capital represents management effort to transform knowledge-based resources into competitive advantage to reduce the entrenchment effect.

The results for OGCA2 shown in Panel A, Table 5 are consistent with our expectations. The coefficients for the main effect of corporate performance are significantly positive for both EBIT/BA and the ROAg sub-sample and negative for AgCost (-0.005). More important, innovation capital is positively related to TR_BV and EBIT/BA. This shows that R\&D inputs and the time effect can improve organization capital through dynamic capacity for improvement of corporate performance in the long run. The results for OGCA2 shown in Panel B, Table 5 (without innovation capital) with only relational capital, are significantly 
positively associated with TR_BV and EBIT/BA. Relational capital has a significant impact on the performance variables, with the exception of effectiveness. Relational capital has perpetual value related to the impact of maintaining customer relationship instead of innovation capital for R\&D activities. Nevertheless, process capital also helps to mitigate the endogeneity concern. Consistent with our hypotheses, we find knowledge-based resources after the establishment of auto-correlated SGA expenditure inputs. The regression results indicate that better intangible assets (no agency problems) leads to lower agency costs, due to reducing the cost of monitoring from the board of directors. Lack of innovation capital, like expropriation by insiders, is a more frequent occurrence when the market is experiencing a downturn than when the market is booming (Durnev, Kim 2005).

Table 5. Organization capital and corporate performance

\begin{tabular}{|c|c|c|c|c|}
\hline \multirow[b]{2}{*}{ Variables } & \multicolumn{4}{|c|}{ Panel A. Innovation capital } \\
\hline & $\begin{array}{c}\text { TR_BV } \\
\text { Total Production }\end{array}$ & $\begin{array}{l}\text { AgCosts } \\
\text { Agent cost }\end{array}$ & $\begin{array}{c}\text { EBIT/BA } \\
\text { EBIT/book value }\end{array}$ & $\begin{array}{c}\text { ROAg } \\
\text { ROA growth \% }\end{array}$ \\
\hline Constant & $\begin{array}{l}0.808^{* * *} \\
(5.03)\end{array}$ & $\begin{array}{l}0.833^{* * *} \\
(3.734)\end{array}$ & $\begin{array}{l}0.135^{* * *} \\
(5.448)\end{array}$ & $\begin{array}{l}1.844 \\
(7.873)\end{array}$ \\
\hline $\begin{array}{l}\text { OGCA1 } \\
\text { Organization Capital }\end{array}$ & $\begin{array}{l}0.040^{* * *} \\
(4.075)\end{array}$ & $\begin{array}{l}-0.007^{* *} \\
(-4.870)\end{array}$ & $\begin{array}{l}0.561^{* * *} \\
(4.870)\end{array}$ & $\begin{array}{l}-0.119^{* * *} \\
(-3.379)\end{array}$ \\
\hline Firm Scale & $\begin{array}{l}-0.104^{* * *} \\
(-4.616)\end{array}$ & $\begin{array}{l}-0.039^{* * *} \\
(-4.333)\end{array}$ & $\begin{array}{l}0.505^{* * *} \\
(3.621)\end{array}$ & $\begin{array}{l}-0.527^{* * *} \\
(-5.090)\end{array}$ \\
\hline Debt ratio & $\begin{array}{l}4.867^{* * *} \\
(3.930)\end{array}$ & $\begin{array}{l}-0.055 \\
(-1.221)\end{array}$ & $\begin{array}{l}0.184^{* * *} \\
(3.594)\end{array}$ & $\begin{array}{l}0.705^{* * *} \\
(3.081)\end{array}$ \\
\hline Adj-R Square & 0.577 & 0.121 & 0.362 & 0.369 \\
\hline Hausman test & $\begin{array}{c}0.958 \\
(0.328)\end{array}$ & $\begin{array}{l}2.847 \\
(0.092)\end{array}$ & $\begin{array}{c}0.164 \\
(0.685)\end{array}$ & $\begin{array}{c}0.457 \\
(0.499)\end{array}$ \\
\hline Variables & $\begin{array}{c}\text { TR_BV } \\
\text { Total production }\end{array}$ & $\begin{array}{c}\text { AgCosts } \\
\text { Agent cost }\end{array}$ & $\begin{array}{c}\text { EBIT/BA } \\
\text { EBIT/book value }\end{array}$ & $\begin{array}{c}\text { ROAg } \\
\text { ROA growth \% }\end{array}$ \\
\hline Constant & $\begin{array}{l}0.813^{* * *} \\
(4.361)\end{array}$ & $\begin{array}{l}0.691^{* * *} \\
(7.450)\end{array}$ & $\begin{array}{l}0.138^{* * *} \\
(3.990)\end{array}$ & $\begin{array}{l}0.125^{* * *} \\
(3.644)\end{array}$ \\
\hline $\begin{array}{l}\text { OGCA2 } \\
\text { Organization capital }\end{array}$ & $\begin{array}{l}-0.008 \\
(-1.339)\end{array}$ & $\begin{array}{l}-0.005^{* * *} \\
(-4.095)\end{array}$ & $\begin{array}{l}0.790^{* * *} \\
(5.234)\end{array}$ & $\begin{array}{l}0.251^{* * *} \\
(3.671)\end{array}$ \\
\hline $\begin{array}{l}\text { IVCA } \\
\text { Innovation capital }\end{array}$ & $\begin{array}{l}0.030^{* * *} \\
(7.201)\end{array}$ & $\begin{array}{l}-0.467^{* * *} \\
(-5.180)\end{array}$ & $\begin{array}{l}0.393^{* * *} \\
(5.230)\end{array}$ & $\begin{array}{l}0.024^{* * *} \\
(5.121)\end{array}$ \\
\hline $\begin{array}{l}\text { ProCA } \\
\text { Process capital }\end{array}$ & $\begin{array}{l}0.003^{* * *} \\
(4.152)\end{array}$ & $\begin{array}{l}-0.008 \\
(-1.129)\end{array}$ & $\begin{array}{l}0.294^{* * *} \\
(3.357)\end{array}$ & $\begin{array}{c}0.018 \\
(0.532)\end{array}$ \\
\hline $\begin{array}{l}\text { ReCA } \\
\text { Relational capital }\end{array}$ & $\begin{array}{c}0.009 \\
(1.097)\end{array}$ & $\begin{array}{c}-0.002 \\
(-0.051)\end{array}$ & $\begin{array}{c}0.001 \\
(5.321)\end{array}$ & $\begin{array}{l}-0.007 \\
(-0.435)\end{array}$ \\
\hline Firm Scale & $\begin{array}{l}-.0115^{* * *} \\
(-3.990)\end{array}$ & $\begin{array}{l}-0.032^{* * *} \\
(-5.246)\end{array}$ & $\begin{array}{c}0.589 \\
(0.734)\end{array}$ & $\begin{array}{l}-0.983^{* * *} \\
(-4.162)\end{array}$ \\
\hline Debt ratio & $\begin{array}{l}4.665^{* * *} \\
8.77\end{array}$ & $\begin{array}{l}-0.020 \\
(-0.445)\end{array}$ & $\begin{array}{l}0.371^{* * *} \\
(2.782)\end{array}$ & $\begin{array}{l}-0.983^{* * *} \\
(-3.162)\end{array}$ \\
\hline Adj-R Square & 0.111 & 0.234 & 0.329 & 0.010 \\
\hline Hausman test & $\begin{array}{c}4.166 \\
(0.384)\end{array}$ & $\begin{array}{c}2.431 \\
(0.657)\end{array}$ & $\begin{array}{c}7.077 \\
(0.132)\end{array}$ & $\begin{array}{c}6.104 \\
(0.192)\end{array}$ \\
\hline
\end{tabular}


End of Table 5

\begin{tabular}{|c|c|c|c|c|}
\hline \multirow[b]{2}{*}{ Variables } & \multicolumn{4}{|c|}{ Panel B. Non-innovation capital } \\
\hline & $\begin{array}{c}\text { TR_BV } \\
\text { Total Production }\end{array}$ & $\begin{array}{c}\text { AgCosts } \\
\text { Agent cost }\end{array}$ & $\begin{array}{c}\text { EBIT/BA } \\
\text { EBIT/book value }\end{array}$ & $\begin{array}{c}\text { ROAg } \\
\text { ROA growth \% }\end{array}$ \\
\hline Constant & $\begin{array}{l}1.49^{* * *} \\
4.361\end{array}$ & $\begin{array}{l}0.692^{* * *} \\
7.450\end{array}$ & $\begin{array}{l}-0.570^{* *} \\
-2.431\end{array}$ & $\begin{array}{l}0.125^{* * *} \\
7.644\end{array}$ \\
\hline $\begin{array}{l}\text { OGCA1 } \\
\text { Organization capital }\end{array}$ & $\begin{array}{l}0.007^{* *} \\
2.294\end{array}$ & $\begin{array}{l}0.0005 \\
0.557\end{array}$ & $\begin{array}{l}0.189^{* * *} \\
3.729\end{array}$ & $\begin{array}{l}-0.0006 \\
-0.436\end{array}$ \\
\hline Firm Scale & $\begin{array}{l}-0.115^{* * *} \\
-5.099\end{array}$ & $\begin{array}{l}-0.032^{* * *} \\
-5.246\end{array}$ & $\begin{array}{l}0.589 \\
0.734\end{array}$ & $\begin{array}{l}-0.983^{* * *} \\
-4.162\end{array}$ \\
\hline Debt ratio & $\begin{array}{l}4.663^{* * *} \\
4.772\end{array}$ & $\begin{array}{l}-0.0196 \\
-0.445\end{array}$ & $\begin{array}{l}0.371^{* * *} \\
5.782\end{array}$ & $\begin{array}{l}4.313^{* * *} \\
3.386\end{array}$ \\
\hline R Square & $15.92 \%$ & $21.47 \%$ & $44.37 \%$ & $17.68 \%$ \\
\hline Variables & $\begin{array}{c}\text { TR_BV } \\
\text { Total production }\end{array}$ & $\begin{array}{l}\text { AgCosts } \\
\text { Agent cost }\end{array}$ & $\begin{array}{c}\text { EBIT/BA } \\
\text { EBIT/book value }\end{array}$ & $\begin{array}{c}\text { ROAg } \\
\text { ROA growth \% }\end{array}$ \\
\hline Constant & $\begin{array}{l}0.149^{* * *} \\
(4.361)\end{array}$ & $\begin{array}{l}0.692^{* * *} \\
(7.450)\end{array}$ & $\begin{array}{l}-0.957^{* *} \\
(-2.431)\end{array}$ & $\begin{array}{l}0.481^{* * *} \\
(7.644)\end{array}$ \\
\hline $\begin{array}{l}\text { OGCA2 } \\
\text { Organization capital }\end{array}$ & $\begin{array}{l}0.006^{* *} \\
(2.294)\end{array}$ & $\begin{array}{l}0.458 \\
(0.557)\end{array}$ & $\begin{array}{l}0.189^{* * *} \\
(3.729)\end{array}$ & $\begin{array}{l}0.006 \\
(0.435)\end{array}$ \\
\hline $\begin{array}{l}\text { ProCA } \\
\text { Process capital }\end{array}$ & $\begin{array}{l}0.023^{* * *} \\
(3.079)\end{array}$ & $\begin{array}{l}-0.003^{* * *} \\
(-2.663)\end{array}$ & $\begin{array}{l}0.308 \\
(1.000)\end{array}$ & $\begin{array}{l}0.268^{* * *} \\
(3.491)\end{array}$ \\
\hline $\begin{array}{l}\text { ReCA } \\
\text { Relational capital }\end{array}$ & $\begin{array}{l}0.572 \\
(1.270)\end{array}$ & $\begin{array}{l}-0.005^{* * *} \\
(-4.097)\end{array}$ & $\begin{array}{l}0.601^{* * *} \\
(3.520)\end{array}$ & $\begin{array}{l}0.251^{* * *} \\
(3.167)\end{array}$ \\
\hline Firm Scale & $\begin{array}{l}-0.115^{* * *} \\
(-3.099)\end{array}$ & $\begin{array}{l}-0.032^{* * *} \\
(-3.246)\end{array}$ & $\begin{array}{l}2.758 \\
(0.734)\end{array}$ & $\begin{array}{l}-0.984^{* * *} \\
(-4.162)\end{array}$ \\
\hline Debt ratio & $\begin{array}{l}4.665^{* * *} \\
(3.778)\end{array}$ & $\begin{array}{l}-0.02 \\
(-0.445)\end{array}$ & $\begin{array}{l}0.371^{* * *} \\
(3.782)\end{array}$ & $\begin{array}{l}4.313^{* * *} \\
(5.586)\end{array}$ \\
\hline Adj-R Square & $15.92 \%$ & $21.47 \%$ & $44.37 \%$ & $11.78 \%$ \\
\hline
\end{tabular}

Notes: This table reports panel data regression estimation of the OGCA1 and OGCA2 model in the Eqation (5). OGCA1 is an aggregated valuation method, to sum the innovation capital, process capital and relational capital; we perform OGCA1 and OGCA2 tests involving these different forms of capital. Panel (A) has innovation capital to be OGCA1, and Panel (B) has to be OGCA1 without innovation capital. We obtain data from 359 sample firms without R\&D inputs and 986 sample firms with R\&D inputs. The superscript asterisks ${ }^{\star},{ }^{* *}$ and ${ }^{* *}$ indicate statistical significance at the $10 \%, 5 \%$ and $1 \%$ levels, respectively, using a two-tailed test, the test is one-tailed when directional predictions are made, and two tailed otherwise.

\subsection{Mediating effect of organisation capital on relationship between board function and corporate performance}

The results from the TSLS regression models have the highest statistical significance and highest explanatory power, yielding coefficients of determination of $61.5,73.3$ and $46.4 \%$ for TR_BV, EBIT/BA and ROAg, respectively. The hypothesis related to the relationship between organization capital and corporate performance is regarded as being strongly, positively statistically supported. The regression coefficient for the independent variables is highest in the model that tests for the influence of the mediation effects. Thus, OGCA2, 
ProCA, IVCA and ReCA can increase performance by increasing production efficiency, EBIT/BA and feedback on ROAg. We continue find the coefficient on TR_BV, EBIT/ $\mathrm{BA}$, and ROAg is positive and statistically significant at the $1 \%$ level. Thus, accounting for endogeneity, using the instrumental variable approach, does not appear to affect our main evidence on the impact of organisation capital on corporate performance, when we regress the residuals of the instrumental variable regressions on the mediating effects are jointly significant, further suggesting that the agency perspective in the board function is exogenous for relationship between organisation capital and corporate performance. The results of the weak instrument test are used to determine whether the F-statistic for all models is greater than 10.3, indicating that board function is a strong instrumental variable.

The Hausman test is also used to explore the regression robustness. The p-value is insignificant and $\mathrm{H}_{0}$ is rejected. The Hausman test result suggests that the OLS results are different from the TSLS results. The results indicate that the endogenous variables are derived from the predictors rather than the data, suggesting that TSLS should be used to replace the OLS. If $\mathrm{H}_{0}$ is not rejected, we suggest using the OLS method to preserve consistency. The TSLS model is used in most cases, with the exception of the EBIT/BA. However, the four endogenous variables have significant effects on corporate performance, with the exception of agency cost. Another concern with our main analysis may be that agency cost is influenced by the governance structures, with directors of board being one of these mechanisms. For example, inside directors maintain a higher monitoring in less risk-taking behavior to improve higher organisation capital. Alternatively, the independent directors may develop surveillance over entrenchment that take less risks because CEO hold more private benefit is not interesting in investing positive-NPV projects in such companies. Given the potential for endogeneity between organisation capital and agency cost, we estimate in model 2 of Table 6. Two systems of OGCA2 and IVCA, ReCA and ProCA as jointly determined. We perform the estimation using TSLS procedure as the results that both IVCA and ReCA are positively and significantly related to corporate performance except for reducing agency cost. More important for our purposes, we continue to find in ProCA is negatively associated with AgCosts and positively associated others and statistically significant at the $1 \%$ level.

Overall, the above analysis provides evidence suggestion that the directors of board have more functions to monitor or consult-insiders, independent director, board size, controller and duality- significantly related to the magnitude of organization capital directly or indirectly effect. Moveover, the effects are larger when the directors of board has delivered the information to joint with decision maker and seem to be greater when there have been changes in the competition. These results suggest that the effect we identify can, at least in part, be attributable to observable characteristics proxy for either board function to monitor and counselling or the dynamic capacity in sustain the competitive advantage for organization capital. 
Table 6. Mediation effect between board function, organization capital and corporate performance

\begin{tabular}{lcccc}
\hline \multirow{2}{*}{ Variables } & Model 1 & Model 2 & Model 3 & Model 4 \\
& TR_BV & AgCosts & EBIT/BA & ROAg \\
\hline Constant & $0.889^{* * *}$ & $0.231^{* * *}$ & $-0.115^{* * *}$ & $0.958^{* *}$ \\
& 3.208 & 12.19 & -2.784 & 2.148 \\
\hline OGCA2 & $0.615^{* *}$ & -0.004 & $0.733^{* * *}$ & $0.464^{* * *}$ \\
& 2.477 & -1.249 & 3.618 & 6.472 \\
\hline IVCA & $0.620^{* * *}$ & -0.005 & $0.769^{* * *}$ & $0.465^{* *}$ \\
Innovation capital & 2.475 & -1.354 & 5.168 & 3.664 \\
\hline ReCA & $1.321^{* * *}$ & 0.006 & $4.424^{* * *}$ & $0.664^{* * *}$ \\
Relational capital & 1.909 & 0.181 & 3.54 & 2.392 \\
\hline ProCA & $1.054^{* * *}$ & $-0.016^{* *}$ & $0.311^{* * *}$ & $0.657^{* * *}$ \\
Process capital & 2.756 & -2.458 & 6.579 & 3.987 \\
\hline R-squares & $24.1 \%$ & $21.8 \%$ & $42.78 \%$ & $11.71 \%$ \\
Hausman test & $36.47^{* * *}$ & $22.9^{* * *}$ & 2.169 & $4.784^{* * *}$ \\
Sargan over-identification test & 1.377 & 4.85 & 3.293 & 19.84 \\
& $(0.502)$ & $(0.000)$ & $(0.05)$ & $(0.000)$ \\
Weak instrument test & $16.86^{* * *}$ & $14.25^{* * *}$ & $21.45^{* * *}$ & $14.25^{* *}$ \\
& $(9.53)$ & $(9.53)$ & $(9.53)$ & $(9.53)$ \\
\hline
\end{tabular}

Notes: Regressions of corporate performance on organization capital and instrumental variables are following corporate performance model:

$$
\begin{gathered}
\tilde{A}_{i, t}=\lambda_{1} \operatorname{Dual}_{i, t}+\lambda_{2} \operatorname{Insdir}_{i, t}+\lambda_{3} \operatorname{IndDir}_{i, t}+\lambda_{4} \mathrm{CFR}_{2} \mathrm{VR}_{i, t}+\lambda_{5} \mathrm{Fami}_{i, t}+\lambda_{6} \text { Boardsize }_{i, t}+\mu_{i, t} ; \\
\mathrm{CP}_{i, t}=\theta_{0}+\theta_{1} \tilde{A}_{i, t}+\theta_{2} \mathrm{IVCA}_{i, t}+\theta_{3} \operatorname{ReCA}_{i, t}+\theta_{4} \operatorname{ProCA}_{i, t}+\varsigma,
\end{gathered}
$$

where organization capital is measure as aggregated model and EP model, aggregated model is the sum of relational capital, process capital and innovation capital and EP model is described by Eq. (4). The dependent variable is TR_BV, AgCosts, EBIT/BA and ROAg. TV_BV is calculated as the ratio of total revenue to total book value of assets, AgCosts measured as operating expenses multiple the residuals which operating expense growth ratio minus annual sales growth ratio. Return on assets is the ratio of EBITDA over lagged total assets; the ROAg is the growth rate of ROA. First-stage regression results predicting board function are unreported. We report the second-stage regressions of corporate performance on fitted-values of organization capital (OGCA2). In the first-stage regressions related to OGCA2, we use the board function predict the equation by EP model. The full sample includes 1,355 listed firms in the Taiwan, we report the robust t-statistic clustered at the firm-levels. The subscript asterisks ${ }^{* * *},{ }^{* *}$, and ${ }^{*}$ denote statistical significance at the $1 \%, 5 \%$ and $10 \%$ levels, respectively. The test is one tailed when directional predictions are made and two-tailed otherwise. A Hausman test of the OLS versus the 2SLS specification indicates that one cannot reject at traditional significance levels the hypothesis that the two estimates are the same. Sargan over-identification tests are used to test the over-identifying restrictions. A weak instrument is also used. The F-statistics from the first-stage regression for each of the potentially endogenous regressors are presented. If the F-statistic exceeds the critical value (using $5 \%$ bias), the instruments are deemed to be valid. ${ }^{*}, * *$ and ${ }^{* * *}$ indicate statistical significance at the $10 \%, 5 \%$ and $1 \%$ levels, respectively, using a two-tailed test. The reported z-statistics are based on the coefficients on the variables. We only use the EP model to proxy variable for organization capital; the equation is as follows:

$$
\mathrm{OOC}_{i, t}=(1-\delta) \mathrm{OCC}_{i, t-1}+\frac{\mathrm{SGA}_{i, t}}{g+\delta} .
$$

We then also list the IVCA, ReCA and ProCA to examine their effect. 


\section{Discussion and conclusions}

There are three key points that can be drawn from results. First, it is confirmed that the relationship is substantially direct path and mediating effect on the corporate performance to describe the governance needs and the consulting service contributions of board function. It is suggested that a more integrative model of all of the elements discussed be developed with the linked tightened between corporate governance and CEO effort. Directors are the firefighters of an organization (Lorsch, Maclver 1989). Second, the results show that organization capital has a strong effect on corporate performance. The measures of organization capital obtained with the EP model are superior to those obtained in prior studies, which implicitly assume that dynamic capabilities moderate sustainable value in organization capital. From this, we derive our measures of board function whether affected through direct or indirect paths (via organization capital). Our EBIT/book value data are the most appropriate for examining corporate performance. This involves different measures for effectiveness, agency problems and growth opportunities. Some variables may affect the generalizability of the results. Three, board function means that directors directly perform different tasks at the same time and each director plays a counselling role within organization, providing knowledge, information and ties to the external environment (Markarian, Parbonetti 2007). Their professional experience leads to organization capital and dynamic capabilities in terms of choices in strategic decision making (Delgado-Verde et al. 2014). On the other hand, we argue that good governance should result in lessening of the agency problem and a lower entrenchment effect. Our results show that directors of the board improve the monitoring effects. Managerial effort thus increases organization capital. Directors represent the interests of shareholders for sustainable long run performance.

We know that when organizational changes occur rapidly, everything is dependent on core competencies, worker skills, and the accumulation of knowledge and the strength of stakeholder networks. This study can help management to intensify initiatives to encourage greater understanding and acceptance of how organization capital can boost a firm's core competence, leading to superior long-term performance. The empirical evidence indicates that the company should provide high quality services and products for sustainable customer relationships. The evidence suggests that the board of directors has a higher effect and management effort helps firms attain higher levels of organizational capital relative to those with weaker board function.

The meditating effect of the board on the association between intellectual capital and corporate performance in Taiwan is also investigated and tested. The mediating effects are examined and a more accurate estimation of the relationship between the variables offered. The conclusions are consistent with those of Saumyendu et al. (2014) and support the intensifying of initiatives to encourage greater understanding and acceptance of the concept of using organisation capital to boost corporate performance to obtain a competitive advantage.

Our research results have broad implications for policy makers. First, the benefits expected to result from organisation innovation and process improvement may have integrated under board function monitor and consult of dynamic capacity (Ghazinoory 
et al. 2014). Moveover, reducing barriers to enforce corporate governance and generating reputation, innovation react to dynamic capacity, which condition the behavior of organisational participants can lead to a significant increase in corporate performance, which is an important driver of a company's competitive advantage and effectiveness. The evidence of function heterogeneity of board has important implications for interpretations of existing evidence on organization capital and corporate performance for future research. Evidence of mediation effect does not necessarily mean that monitoring action play no influences for reducing agency cost regarding EP model for organization capital, the surveillance of directors cannot response for variant-environment in the face of management efforts. Our evidence on board function also introduces a number of questions for future research, for example, in this article we study board function among listed Taiwan firms, but how do our findings compare to those firm samples of groups, where the scope for influence might be greater, or countries, and competitive environments with different corporate governance systems?

\section{Notes}

1. After American bankruptcy courts accepted Kodak's plan for reorganisation they forged an agreement to arrange for new financing and a restructured board that would provide the company with a strong, stable capital structure. It is surprising that Kodak had been a successful business generating profits in the past. Kodak chairman and chief executive Antonio Perez made the following statement:

"Now we must complete the transformation by further addressing our cost structure and effectively monetizing non-core-intellectual-property assets. We look forward to working with our stakeholders to emerge as a lean, world-class, digital imaging and materials science company," cited from "Kodak files for bankruptcy, secures lifeline", Taipei Times, January 20, 2012 (Reuters 2012).

2. Efficient process capital will create favourable conditions for customers:

ProCA $=[$ Operating benefit- $($ current profits + income tax $)] \div$ staff number.

Innovation capital can be expressed as:

$$
\mathrm{IVCA}=\frac{\mathrm{EAT}}{\mathrm{R} \& \mathrm{D}}
$$

where EAT indicates earnings after taxes and R\&D indicates research and development expenditure.

Related capital (ReCA) is defined as follows:

$$
\operatorname{ReCA}_{i, t}=\frac{\mathrm{SGA}}{\mathrm{EVA}},
$$

EVA $=$ Net Operating Profit After Tax (NOPAT) $-($ Cost of Capital $) \times$ Net Asset Value.

3. De, Dutta (2007) and Tronconi, Marzetti (2011) assumed the depreciation rate to be $10 \%$. 
4. The definition of SGA expense states that this item represents all commercial expenses for options incurred in the regular course of business pertaining to the securing of operating income of U. S. GAAP.

5. Ruiz-Mallorqui, Santana-Martin (2011) posit the dominant owner's cash flow rights represent on average $88 \%$ (bank) and $94 \%$ (investment fund) on average of its cash flow right to voting right.

\section{References}

Abdullah, S. N. 2004. Board composition, CEO duality and performance among Malaysian listed companies, Corporate Governance 4(4): 47-61. http://dx.doi.org/10.1108/14720700410558871

Abeysekera, J. 2010. The influence of board size on intellectual capital disclosure by Kenyan listed firms, Journal of Intellectual Capital 11(4): 504-518. http://dx.doi.org/10.1108/14691931011085650

Adjaoud, F.; Zegha, I. D.; Andaleeb, S. 2007. The effect of boards quality on performance: a study of Canadian firms, Corporate Governance: An International Review 15(4): 623-635.

Albuquerque, R.; Wang, N. 2008. Agency conflicts, investment and asset pricing, Journal of Finance 63(1): 1-40. http://dx.doi.org/10.1111/j.1540-6261.2008.01309.x

Anderson, K. A.; Deli, D. N.; Gillan, S. L. 2004. Boards of directors, audit committees and the information content of earnings. Working paper. Georgetown University.

Andreou, A. N.; Green, A.; Stankosky, M. 2007. A framework of intangible valuation areas and antecedents, Journal of Intellectual Capital 8(1): 52-75. http://dx.doi.org/10.1108/14691930710715060

Atkeson, A.; Kehoe, P. J. 2005. Modeling and measuring organisation capital, Journal of Political Economy 113(5): 1026-1053. http://dx.doi.org/10.1086/431289

Barbier, E. B. 1987. The concept of sustainable economic development, Environmental Conservation 14(2): 101-110. http://dx.doi.org/10.1017/S0376892900011449

Bastos, F. R. 2007. Organisational capital, learning-by-doing and investment volatility, Economia: revista quadrimestral publicada pela ANPEC 8(3): 1-13.

Baysinger, B. D.; Hoskisson, R. E. 1990. The composition of boards of directors and strategic control effects on corporate strategy, Academy of Management Review 15(1): 72-87.

Baysinger, B. D.; Kosnik, R. D.; Turk, T. A. 1991. Effects of board and ownership structure on corporate R\&D strategy, Academy of Management Journal 34(1): 205-214. http://dx.doi.org/10.2307/256308

Belo, F.; Vitorino, M. A.; Lin, X. 2014. Brand capital, firm value and asset returns, Review of Economic Dynamics 17(1): 150-169. http://dx.doi.org/10.1016/j.red.2013.05.001

Benevene, P.; Cortini, M. 2010. Interaction between structural capital and human capital in Italian NPOs, Journal of Intellectual Capital 11(2): 123-139. http://dx.doi.org/10.1108/14691931011039642

Black, S. E.; Lynch, L. M. 2005. Measuring organisational capital in the new economy. NBER Chapters, National Bureau of Economic Research, Inc., 205-236.

Boeker, W. 1992. Power and managerial dismissal: scapegoating at the top, Administrative Science Quarterly 37(3): 400-421. http://dx.doi.org/10.2307/2393450

Bontis, N. 2001. Assessing knowledge assets: a review of the models used to measure intellectual capital, International Journal of Management Reviews 3(1): 41-60. http://dx.doi.org/10.1111/1468-2370.00053

Bontis, N.; Chua, W.; Richardson, S. 2000. Intellectual capital and business performance in Malaysian industries, Journal of Intellectual Capital 1(1): 85-100. http://dx.doi.org/10.1108/14691930010324188 
Bontis, N. 1999. Managing organizational knowledge by diagnosing intellectual capital: framing and advancing the state of the field, Intellectual Journal of Technology Management 18(5-8): 433-462. http://dx.doi.org/10.1504/IJTM.1999.002780

Bontis, N.; Booker, D.; Serenko, A. 2007. The mediating effect of organisational reputation on customer loyalty and service recommendation in the banking industry, Management Decision 45(9): 14261445. http://dx.doi.org/10.1108/00251740710828681

Boone, A.; Field, L.; Karpoff, J.; Raheja, C. 2007. The determinants of corporate board size and composition: an empirical analysis, Journal of Financial Economics 85(1): 66-101. http://dx.doi.org/10.1016/j.jineco.2006.05.004

Boyd, B. K. 1995. CEO duality and firm performance: a contingency model, Strategic Management Journal 16(4): 301-312. http://dx.doi.org/10.1002/smj.4250160404

Boyd, B. K. 1994. Board control and CEO compensation, Strategic Management Journal 15(5): 335-344. http://dx.doi.org/10.1002/smj.4250150502

Byrd, J.; Hickman, K. 1992. Do outside directors monitor managers? Evidence from tender offer bids, Journal of Financial Economics 32(2): 195-221. http://dx.doi.org/10.1016/0304-405X(92)90018-S

Carayannis, E. G.; Alexander, J. 2002. Is technological learning a firm core competence, when, how and why? A longitudinal multi-industry study of firm technological learning and market performance, Technovation 22(10): 625-543. http://dx.doi.org/10.1016/S0166-4972(01)00047-5

Carpenter, M. A.; Sanders, W. G.; Gregersen, H. B. 2001. Bundling human capital with organisation context: the impact of international assignment experience on multinational firm performance and CEO play, Academy of Management Journal 44(3): 493-512. http://dx.doi.org/10.2307/3069366

Chen, S.; Chen, I. 2012. Corporate governance and capital allocation of diversified firms, Journal of Banking \& Finance 36(2): 395-409. http://dx.doi.org/10.1016/j.jbankfin.2011.07.013

Chen, K. C. W.; Chen, Z.; Wei, K. C. J. 2011. Agency costs of free cash flow and the effect of shareholder rights on the implied cost of equity capital, Journal of Financial and Quantitative analysis 46(10): 171-207. http://dx.doi.org/10.1017/S0022109010000591

Chen, M. C.; Cheng, S. J.; Hwang, Y. 2005. An empirical investigation of the relationship between intellectual capital and firms' market value and financial performance, Journal of Intellectual Capital 6(2): 159-176. http://dx.doi.org/10.1108/14691930510592771

Čiutienè, R.; Meilienè, E.; Savanevičienè, A.; Vaitkevičius, S. 2015. Interdependence between human capital and the power of a shadow economy: Lithuanian case study, Technological and Economic Development of Economy 21(3): 460-482. http://dx.doi.org/10.3846/20294913.2015.1017864

Claessens, S.; Djankov, S.; Lang, H. P. L. 2000. The separation of ownership and control in East Asia corporations, Journal of Financial Economics 58(1-2): 81-112. http://doi:10.1016/S0304-405X(00)00067-2

Claessens, S.; Djankov, S.; Fan, J. P. H.; Larry, H. P. L. 2002. Disentangling the incentive and entrenchment effects of large shareholdings, The Journal of Finance 57(6): 2741-2771.

Clarkson, M. B. E. 1994. A risk based model of stakeholder theory the centre for corporate social performance and ethics. University of Toronto, Toronto, Canada.

Cotter, J. F.; Shivdasani, A.; Zenner, M. 1997. Do independent directors enhance target shareholder wealth during tender offer?, Journal of Financial Economics 43(2): 195-218. http://dx.doi.org/10.1016/S0304-405X(96)00886-0

Daily, C. M.; Dalton, D. R. 1995. CEO and director turnover in failing firms: an illusion of change?, Strategic Management Journal 16(5): 393-400. http://dx.doi.org/10.1002/smj.4250160505

Dalton, D. R.; Daily, C. M.; Ellstrand, A. E.; Johnson, J. L. 1998. Meta-analytic reviews of board composition, leadership structure and financial performance, Strategic Management Journal 19(3): 269-290. http://dx.doi.org/10.1002/(SICI)1097-0266(199803)19:3<269::AID-SMJ950>3.0.CO;2-K 
Daud, S.; Yusoff, W. F. W. 2011. How intellectual capitals mediate the relationship between knowledge management processes and organisation performance?, African Journal of Business Management 5(7): 2607-2617.

De, S.; Dutta, D. 2007. Impact of intangible capital on productivity and growth: lessens from the Indian information technology software industry?, Economic Record 83(Supplement S1): S73-S86. http://dx.doi.org/10.1111/j.1475-4932.2007.00406.x

Delgado-Verde, M.; Amores-Salvado, J.; Martin-de Castro, G.; Navas-Lòpez, J. E. 2014. Green intellectual capital and environmental product innovation: the mediating role of green social capital, Knowledge Management Research \& Practice 12(3). http://dx.doi.org/10.1057/kmrp.2014.8

Demirag, I.; Sudarsanum, S.; Wright, M. 2000. Corporate governance overview and research agenda, British Accounting Review 32(4): 341-354. http://dx.doi.org/10.1006/bare.2000.0146

Demsetz, H.; Lehn, K. 1985. The structure of corporate ownership: causes and consequences, Journal of Political Economy 93(6): 1155-1177. http://dx.doi.org/10.1086/261354

de Pablos, P. O. 2002. Evidence of intellectual capital measurement from Asia, Europe and Middle East, Journal of Intellectual Capital 3(3): 287-302. http://dx.doi.org/10.1108/14691930210435624

Dittmar, A.; Mahrt-Smith, J. 2007. Corporate governance and the value of cash holdings, Journal of Financial Economics 83(3): 599-634. http://dx.doi.org/10.1016/j.jfineco.2005.12.006

Donaldson, L.; Davis, J. H. 1991. Stewardship theory or agency theory: CEO governance and shareholder returns, Australian Journal of Management 16(1): 49-64. http://dx.doi.org/10.1177/031289629101600103

Donaldson, L.; Davis, J. H. 1994. Boards and company performance-research challenges the conventional wisdom, Corporate Governance: An International Review 2(3): 151-160.

Durnev, A.; Kim, E. H. 2005. To steal or not to steal: firm attributes, legal environment and valuation, The Journal of Finance 60(3): 1461-1493.

Edvinsson, L. M.; Malone, S. 1997. Intellectual capital realizing your company's true value by finding its hidden brainpower. New York: Harper Business.

Eisenberg, T.; Sundgren, S.; Wells, M. 1998. Larger board size and decreasing firm value in small firms, Journal of Financial Economics 48(1): 35-54. http://dx.doi.org/10.1016/S0304-405X(98)00003-8

Eisenhardt, K. M.; Bourgeois, L. J. 1988. Politics of strategic decision making in high velocity environments: towards a midrange theory, Academy of Management Journal 31(4): 737-770. http://dx.doi.org/10.2307/256337

Eisfeldt, A.; Papanikolaou, D. 2013. Organisation capital and the cross-section of expected return, The Journal of Finance 68(4): 1365-1406. http://dx.doi.org/10.1111/jofi.12034

Fairer, S.; Stainbank, L. 2003. Testing the relationship between intellectual capital and company's performance: evidence from South Africa, Meditari Accountancy Research 11(4): 25-44. http://dx.doi.org/10.1108/10222529200300003

Fama, E. F. 1980. Agency problems and theory of the firm, Journal of Political Economy 88(2): 288-307. http://dx.doi.org/10.1086/260866

Fama, E, F.; Jensen, M. 1983. Separation of ownership and control, Journal of Law and Economics 26(2): 301-325. http://dx.doi.org/10.1086/467037

Filatotchev, I.; Lien, Y.; Piesse, I. 2005. Corporate governance and performance in publicly listed, familycontrolled firms: evidence from Taiwan, Asia Pacific Journal of Management 22(3): 257-283. http://dx.doi.org/10.1007/s10490-005-3569-2

Firer, S.; William, M. S. 2003. Intellectual capital and traditional measures of corporate performance, Journal of Intellectual Capital 4(3): 348-360. http://dx.doi.org/10.1108/14691930310487806

Gan, K.; Saleh, Z. 2008. Intellectual capital and corporate performance of technology-intensive companies: Malaysia evidence, Asian Journal of Business and Accounting 1(1): 113-130. 
Garmaise, M. J.; Liu, J. 2005. Corruption, firm governance, and the cost of capital. Working paper. University of California at Los Angeles.

Ghazinoory, S.; Adel Azar, R. R.; Miremadi, T. 2014. Measuring innovation performance of developing regions: learning and catch-up in provinces of Iran, Technological and Economic Development of Economy 20(3): 507-533. http://dx.doi.org/10.3846/20294913.2014.881433

Gomes, J.; Kogan, L.; Zhang, L. 2003. Equilibrium cross section of returns, Journal of Political Economy 111(4): 693-732. http://dx.doi.org/10.1086/375379

Halim, S. 2010. Statistical analysis on the intellectual capital statement, Journal of Intellectual Capital 11(1): 61-73. http://dx.doi.org/10.1108/14691931011013334

Hall, H; Goody, M. 2007. KM, culture and compromise: interventions to promote knowledge sharing supported by technology in corporate environments, Journal of Information Science 33(2): 181-188. http://dx.doi.org/10.1177/0165551506070708

Hermalin, B.; Weisbach, M. 2003. Boards of directors as an endogenously determined institution: a survey of the economic literature, FRBNY Economic Review April: 7-26.

Hsu, Y.; Fang, W. 2009. Intellectual capital and new product development performance: the mediating role of organisational learning capability, Technological Forecasting \& Social Change 76(5): 664-672. http://dx.doi.org/10.1016/j.techfore.2008.03.012

Hunt, S. D.; Morgan, R. M. 1995. The comparative advantage theory of competition, Journal of Marketing 59(2): 1-15. http://dx.doi.org/10.2307/1252069

Jensen, M. C.; Meckling, W. H. 1976. Theory of the firm: managerial behavior, agency cost, and ownership structure, Journal of Financial Economics 3(4): 305-360. http://dx.doi.org/10.1016/0304-405X(76)90026-X

Jensen, M. C. 1993. The modern industrial revolution, exit, and the failure of internal control systems, Journal of Finance 48(3): 831-880. http://dx.doi.org/10.1111/j.1540-6261.1993.tb04022.x

Juma, N.; Payne, G. T. 2004. Intellectual capital and performance of new venture high-tech firms, International Journal of Innovation Management 8(3): 207-318. http://dx.doi.org/10.1142/S1363919604001076

Kamukama, N.; Ahiauzu, A.; Ntayi, J. M. 2011. Competitive advantage: mediation of intellectual capital and performance, Journal of Intellectual Capital 12(1): 152-164. http://dx.doi.org/10.1108/14691931111097953

Kaplan, R. S.; Norton, D. P. 2004. Measuring the strategic readiness of intangible assets, Harvard Business Review 82(2): 52-63.

Kaymak, T.; Bektas, E. 2008. East meets west? Board characteristics in an emerging market: evidence from Turkish banks, Corporate Governance: An International Review 16(6): 550-561.

Kim, K.; Al-Shammari, H. A.; Kim, B.; Lee, S. 2009. CEO duality leadership and corporate diversification behaviour, Journal of Business Research 62(11): 1173-1180.

http://dx.doi.org/10.1016/j.jbusres.2008.10.017

Kim, S. K.; Lee, B. G.; Park, B. S.; Oh, K. S. 2011. The effect of technology commercialization capabilities and innovation performance, Technological and Economic Development of Economy 17(4): 563-578. http://dx.doi.org/10.3846/20294913.2011.603481

Klein, A. 1998. Firm performance and board committee structure, Journal of Law and Economics 41(1): 275-303. http://dx.doi.org/10.1086/467391

Knight, D. J. 1999. Performance measures for increasing intellectual capital, Strategy and Leadership 27(2): 22-27. http://dx.doi.org/10.1108/eb054632

Kogan, L.; Papanikolaou, D. 2010. Growth opportunities and technology shocks, The American Economic Review 100(2): 532-536. http://dx.doi.org/10.1257/aer.100.2.532 
Kuo, M.; Yang, C. 2012. Does intellectual capital matter? Assessing the profitability and marketability of IC design companies, Quality \& Quantity 46(6): 1865-1887. http://dx.doi.org/10.1007/s11135-011-9562-6

La Porta, R.; Lopez-de-Silanes, F.; Shleifer, A.; Vishny, R. 1998. Law and finance, Journal of Political Economy 106(6): 1113-1155. http://dx.doi.org/10.1086/250042

Lampel, J.; Bhalla, A.; Jha, P. P. 2014. Does governance confer organisational resilience? Evidence from UK employee owned businesses, European Management Journal 32(1): 66-72. http://dx.doi.org/10.1016/j.emj.2013.06.009

Li, J.; Harrison, J. R. 2008. National culture and the composition and leadership structure of boards of directors, Corporate Governance: An International Review 16(5): 375-385.

Lin, X. 2009. Endogenous technological progress and the cross section of stock returns. FMG discussion papers. Financial Markets Group.

Lin, M. J.; Lee, D. C.; Lee, L. T. 2012. The relationship between corporate governance, intellectual capital and corporate social performance, International Research Journal of Finance and Economics 92(1): 59-92.

Ling, Y. H. 2013. The influence of intellectual capital on organisation performance-knowledge management as moderator, Asia Pacific Journal of Management 30(3): 937-964. http://dx.doi.org/10.1007/s10490-011-9257-5

Lorsch, J. W.; Maclver, E. 1989. Pawns or potentates: the reality of America's corporate boards. Boston MA: Harvard Business School Press.

Lustig, H.; Syverson, C.; Van Nieuwerburgh, S. 2011. Technological change and the growing inequality in managerial compensation, Journal of Financial Economics 99(3): 601-627. http://dx.doi.org/10.1016/j.jfineco.2010.09.007

Lynn, B. E. 2003. Culture and intellectual capital management: a key factor in successsful ICM implementation, International Journal of Technology Management 18(5-6): 590-603.

Maditinos, D.; Chatzoudes, D.; Tsairidis, C.; Theriou, G. 2011. The impact of intellectual capital on firms' market value and financial performance, Journal of Intellectual Capital 12(1): 132-151. http://dx.doi.org/10.1108/14691931111097944

Markarian, G.; Parbonetti, A. 2007. Firm complexity and board of director composition, Corporate Governance: An International Review 15(6): 1224-1243.

Martin-de-Castro, G.; Navas-Lòpez, J. E.; Lòpez-Sàez, P.; Alama-Salazar, E. 2006. Organisation capital as competitive advantage of the firms, Journal of Intellectual Capital 7(3): 324-337. http://dx.doi.org/10.1108/14691930610681438

McConnell, J. J.; Servaes, H. 1995. Equity ownership and the two faces of debt, Journal of Financial Economics 39(1): 131-157. http://dx.doi.org/10.1016/0304-405X(95)00824-X

Milliken, E.; Vollrath, O. 1991. Strategic decision making tasks and group effectiveness: insights from theory and research on small group performance, Human Relation 44(12): 1229-1253.

http://dx.doi.org/10.1177/001872679104401201

Minichilli, A.; Corbetta, G.; MacMillan, I. C. 2010. Top management team in family-controlled companies "Familiness", "Faultlines", and their impact on financial performance, Journal of Management Studies 47(2): 205-228. http://dx.doi.org/10.1111/j.1467-6486.2009.00888.x

Moeller, K. 2009. Intangible and financial performance causes and effects, Journal of Intellectual Capital 10(2): 224-245. http://dx.doi.org/10.1108/14691930910952632

Morck, R.; Shleifer, A.; Vishny, R. 1988. Management ownership and market valuation: an empirical analysis, Journal of Financial Economics 20: 293-315.

http://dx.doi.org/10.1016/0304-405X(88)90048-7 
Narver, J. C.; Slater, S. F. 1990. The effect of a market orientation on business profitability, Journal of Marketing 55(4): 20-35. http://dx.doi.org/10.2307/1251757

Nicholson, G. J.; Kiel, G. C. 2007. Can directors impact performance? A case-based test of three theories of corporate governance, Corporate Governance: An International Review 15(4): 585-608. http://dx.doi.org/10.1111/j.1467-8683.2007.00590.x

Peppard, J.; Rylander, A. 2001. Using an intellectual capital perspective to design and implement a growth strategy: the case of APiON, European Management Journal 19(5): 510-525. http://dx.doi.org/10.1016/S0263-2373(01)00065-2

Prescott, E. C.; Visscher, M. 1980. Organisation capital, Journal of Political Economy 78(1): 187-202.

Public, A. 2004. Intellectual capital-does it creates or destroys value?, Measuring Business Excellence 8(1): 62-68. http://dx.doi.org/10.1108/13683040410524757

Ruiz-Mallorqui, M. V.; Santana-Martin, D. J. 2011. Dominant institutional owners and firm value, Journal of Banking and Finance 35: 118-129. http://dx.doi.org/10.1016/j.jbankfin.2010.07.020

Rodgers, W.; Housel, T. J. 2009. Measures for organisations engaged in a knowledge economy, Journal of Intellectual Capital 10(3): 341-353. http://dx.doi.org/10.1108/14691930910977770

Rosen, S. 1972. Learning by experience as joint production, Quarterly Journal of Economics 86(3): 366-382. http://dx.doi.org/10.2307/1880798

Reuters. 2012. Kodak files for bankruptcy, secures lifeline, Taipei Times, 20 January 2012 (Friday) [online], [cited 20 January 2012]. Available from Internet:http://www.taipeitimes.com/News/front/ archives/2012/01/20/2003523657

Saumyendu, G.; Lauren, B.; Mirosław J. S.; Sam, N.; Young, H. K. 2014. Organizational governance to integrate sustainability projects: a case study, Technological and Economic Development of Economy 20(1): 1-24. http://dx.doi.org/10.3846/20294913.2014.850755

Sampson, P. D.; Streissguth, A. P.; Barr, H. M.; Buokstein, F. L. 1989. Neurobehavioral effects of prenatal alchohol: Part II partial least squares analysis, Neurocoxicology and Teratology 11: 477-491. http://dx.doi.org/10.1016/0892-0362(89)90025-1

Schweiger, D.; Sandberg, W.; Ragan, J. 1986. Group approaches for improving strategic decision making: a comparative analysis of dialectical inquiry, devil's advocacy, and consensus, Academy of Management Journal 29(1): 51-71. http://dx.doi.org/10.2307/255859

Serenko, A.; Bontis, N.; Hardie, T. 2007. Organisation size and knowledge flow: a proposed theoretical link, Journal of Intellectual Capital 8(4): 610-627. http://dx.doi.org/10.1108/14691930710830783

Stewart, T. A. 1997. Intellectual capital: the new wealth of organisations. New York: Doubleday.

Sullivan, P. H. 2000. Value-driven intellectual capital: how to convert intangible corporate assets into market value. New York: Wiley.

Sveiby, K. E. 2002. Methods for measuring intangible assets Chapter 1, in D. Morey, M. Maybury, B. Thuraisingham (Eds.). Knowledge management: classic and contemporary. Massachusetts, USA: MIT Press.

Ting, W. I.; Lean, H. H. 2009. Intellectual capital performance of financial institutions in Malaysia, Journal of Intellectual Capital 10(4): 588-599. http://dx.doi.org/10.1108/14691930910996661

Tribo, J. A.; Berrone, P.; Surroca, J. 2007. Do the type and number of blockholders influence R \& D investments? New evidence from Spain, Corporate Governance: An International Review 15(5): $828-842$.

Tronconi, C.; Marzetti, G. V. 2011. Organization capital and firm performance: empirical evidence for European firms, Economics Letters 112(2): 141-143. http://dx.doi.org/10.1016/j.econlet.2011.04.004

Tseng, K.; Lan, Y.; Lu, M.; Chen, P. 2013. Mediation of strategy on intellectual capital and performance, Management Decision 51(7): 1488-1509. http://dx.doi.org/10.1108/MD-03-2012-0143 
Urban, G. L.; Hauser, J. R. 1993. Design and marketing of new products. $2^{\text {nd }}$ ed. Englewood Cliffs, NJ: Prentice-Hall.

Wang, M. S. 2011. Measuring the intellectual capital and their effect on financial performance: evidence from capital market in Taiwan, Frontiers of Business Research in China 5(2):171-189. http://dx.doi.org/10.1007/s11782-011-0130-7

Wang, J. C. 2008. Investigating market value: and intellectual capital for S \& P 500, Journal of Intellectual Capital 9(4): 546-563. http://dx.doi.org/10.1108/14691930810913159

Wang, W. Y.; Chang, C. F. 2005. Intellectual capital and performance in casual models evidence form the information technology industry in Taiwan, Journal of Intellectual Capital 6(2): 222-236. http://dx.doi.org/10.1108/14691930510592816

Wernerfelt, B. 1984. A resource-based view of the firm, Strategic Management Journal 5(2): 171-180. http://dx.doi.org/10.1002/smj.4250050207

Williams, S. M. 2000. Relationship between Board Structure and a Firm's Intellectual Capital Performance in an Emerging Economy. Working Paper. University of Calgary.

Wu, M.; Lee, Y.; Wang, G. 2012. To verify how intellectual capital affects organization performance in listed Taiwan IC design companies with considering the moderator of corporate governance, The Journal of Global Business Management 8(1): 20-32.

Yeh, Y.; Lee, T.; Woidtke, T. 2003. Family control and corporate governance: evidence from Taiwan, International Review of Finance 2(1-2): 21-48.

Yermack, D. 1996. Higher market valuation of companies with a small board of directors, Journal of Financial Economics 40(2): 185-211. http://dx.doi.org/10.1016/0304-405X(95)00844-5

Zahra, S. A.; Pearce, J. A. 1989. Boards of directors and financial performance: a review and integrative model, Journal of Management 15(2): 291-334. http://dx.doi.org/10.1177/014920638901500208

Mu-Shun WANG, Ph. Doctor, Associate Professor, the Dean at the graduate school of banking and finance, Kainan University in Taiwan (ROC), author of more than 20 scientific articles. Research interests: science and technological management, technology and innovation investment, project management and sustainable development.

Shih-Tong LU. Doctor, Professor in the Department of Banking and Finance at Kainan University and certificated in Project Management Professional (PMP). Previously Lu served as an auditing officer in the Taipei Division, National Audit Office. Lu obtained a B.S. and M.S. in Economics from National Chung Hsing University and a PhD in Construction Engineering Management from the National Central University of Taiwan. Lu has acquired more than two decades of experience in the private and public sectors in the financial and construction industry and five years experience in the property management industry. Lu's teaching and research interests include project risk management, quantitative methods for business operations, multiple criteria decision analysis, and quality management. 